\title{
INTERPRETING SUI GENERIS TREATIES
}

\section{JAMES [SÁKÉJ] YOUNGBLOOD HENDERSON*}

This article explores the interpretive principle of sui generis treaties introduced by the Supreme Court of Canada since the repatriation of the Constitution in 1982. The article proceeds through an analysis of treaty rights as constitutional rights, contextual analysis of Indian Treaties, the intent of the treaty parties and the principles which govern the interpretation of treaty text. The author concludes that the principles articulated by the Supreme Court of Canada are an attempt to affirm and enhance Aboriginal worldviews and cognitive diversity within the Constitution of Canada.
L'auteur examine le principe d'interprétation des traités sui generis invoqué par la Cour suprême du Canada depuis le rapatriement de la Constitution en 1982. Il se penche ensuite sur les droits issus de traités en tant que droits constitutionnels, sur l'intention des parties aux traités et les principes gouvernant l'interpnétation du texte des traités. Il conclut que les principes énoncés par la Cour suprême du Canada tentent d'affirmer et de promouvoir la vision du monde et la diversité cognitive des autochtones au sein de la Constitution canadienne.

\section{TABLE OF CONTENTS}

I. INTRODUCTION $\ldots \ldots \ldots \ldots \ldots \ldots \ldots \ldots \ldots \ldots \ldots \ldots \ldots \ldots \ldots$

II. INDIAN TREATY RIGHTS AS

CONSTITUTIONAL RIGHTS .................49

III. Contextual ANALYSIS OF Indian TREATIES $\ldots \ldots \ldots \ldots \ldots \ldots 6$

A. Historical Contexts $\ldots \ldots \ldots \ldots \ldots \ldots \ldots \ldots$

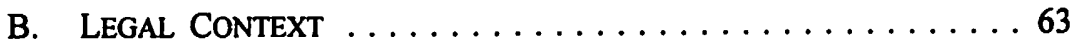

C. REJECTING COLONIAL OR RACIAL

Bias In ConteXtual ANALYSIS $\ldots \ldots \ldots \ldots \ldots \ldots \ldots 6$

IV. INTENT OF THE TREATY PARTIES $\ldots \ldots \ldots \ldots \ldots \ldots \ldots \ldots 71$

A. PRotection of the ABoriginal

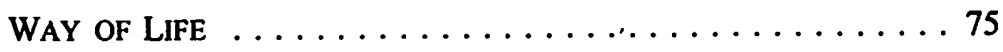

B. Crown Obligations to Create aN

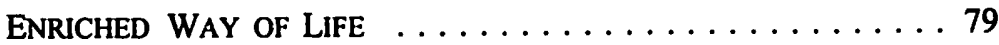

C. THE HONOUR OF THE CROWN $\ldots \ldots \ldots \ldots \ldots \ldots \ldots \ldots . \ldots$

V. INTERPRETING TREATY TEXT $\ldots \ldots \ldots \ldots \ldots \ldots \ldots \ldots \ldots . \ldots 1$

A. Rejecting the Plain Meaning of TeXt $\ldots \ldots \ldots \ldots \ldots 84$

B. SYNTAX ParadoXes $\ldots \ldots \ldots \ldots \ldots \ldots \ldots \ldots$

C. FAIR, LARGE, AND LIBERAL INTERPRETATION

OF TREATY TEXT IN Favour of Indians $\ldots \ldots \ldots \ldots \ldots 91$

D. IN FAVOUR OF ABORIGINAL WORLDVIEW

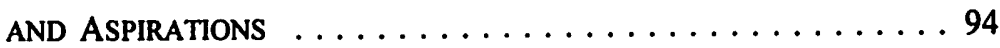

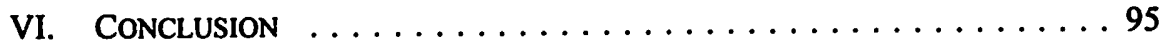

Research Director, Native Law Centre of Canada, College of Law, University of Saskatchewan. Guidance provided by ababinilli, máheóo, and niskam; although I assume full responsibility for interpretation. Special reverence is due to the elders, who have continued the teachings of Aboriginal languages and treaties to the youth, despite domination and oppression. 


\section{INTRODUCTION}

Since the repatriation of the Indian treaty rights in the Canadian Constitution, the Supreme Court of Canada has established a series of principles to assist justices who have to interpret sui generis treaties and existing treaty rights.' These interpretive principles are rigorous. They require a justice who is reviewing a challenge to an Indian treaty to move into an interpretive consciousness that allows alternate views of time, law, and culture. This shift in consciousness is necessary because most of the sui generis treaties are derived from grants from Aboriginal nations to the imperial Crown and, as such, arose out of Aboriginal order. The interpretive consciousness has many levels: establishing the relationship of the treaties to the Constitution, reviewing historical and legal contexts for the treaties, discovering the intent of the treaty parties, and analyzing the text of the treaties. All levels of interpretation are necessary and all are interrelated.

At the first level, the constitutional level, the interpretative principles require an interpreting judge to read the treaty along with other parts of the Constitution of Canada. ${ }^{2}$ This requires an interpreting judge to develop a theory of convergence among the diverse parts of constitutional law. Any limitation or modification of treaty rights or obligations by other constitutional documents must be proven by clear and plain wording in positive law by the Crown, rather than by government. ${ }^{3}$ A judicial determination or a unilateral modification of treaty rights or obligations cannot extinguish the treaty because of its source and its continuing force of law.

At the second level, the interpretative principles authorize an interpreting justice to undertake a review of the historical and legal contexts of the treaty. ${ }^{4}$ In this contextual review, an interpreting judge must remain faithful to the idea that the exchange of solemn promises between the imperial Crown and Aboriginal nations is a fundamental agreement of a sacred nature ${ }^{5}$ that has always been considered legally binding. ${ }^{6}$ Such an agreement creates and sustains fiduciary obligations between the treaty parties.

At the third level, the interpretive principles stress that the spirit and intent of treaty obligations and rights must be approached in a manner that maintains the integrity and honour of the Crown and the Aboriginal nations. ${ }^{8}$ The motivations of both treaty parties form the mutual foundation of the promise or agreement and give the promise

R. v. Badger, [1996] 2 C.N.L.R. 77 (S.C.C.) [hereinafter Badger]; R v. Horseman, [1990] 1 S.C.R. 901 [hereinafter Horseman]; R. v. Sioui, [1990] I S.C.R. 1025 [hereinafter Sioui]; and Simon v. $R$, [1985] 2 S.C.R. 387 at 404 [hereinafter Simon]. For a history of the treaty making with Aboriginal nations, see Report of the Royal Commission on Aboriginal Peoples, vol. 1., Looking Forward, Looking Back (Ottawa: Minister of Supply and Services Canada, 1996) at 119-28 and 155-71 [hereinafter Royal Commission Volume 1].

Badger, ibid. at 90, 92-93, 94, 104, 107 (paras. 37, 43, 47, 72, 84).

Ibid. See R. v. Sparrow, [1990] I S.C.R. 1075 [hereinafter Sparrow].

Badger, supra note 1 at 95 (para. 52); Horseman, supra note 1 at 906; Sioui, supra note 1 at 1035.

Badger, ibid. at $91-94$ (paras. 41, 47); Sioui, ibid. at 1063; Simon, supra note 1 at 401.

Badger, ibid. at 94 (para. 47); Sioui, ibid:; Simon, ibid.

Badger, ibid. See also ibid. at 111 (para. 97).

Ibid. at 111 (para. 97). 
its validity. ${ }^{9}$ Such motivations must be interpreted in terms of the worldview of both parties, since each worldview independently justifies the party having entered into the agreement. ${ }^{10}$

At the fourth level, the interpretive principles require an interpreting judge to assume that the Crown and the Aboriginal nations intended to fully comply with each promise, obligation, or right laid out in the treaty. "This requires a detailed examination of the treaty text and requires that each term be approached with a large, liberal, and generous interpretation in favour of the Indians. ${ }^{12}$ Similarly, any uncertainties, ambiguities, or doubtful expressions must be resolved in favour of the Indians. ${ }^{13}$ This also applies to constitutional, federal, and provincial laws regulating Indians. ${ }^{14} \mathrm{~A}$ corollary principle establishes that any limitations that restrict the rights of Indians under treaties must be narrowly construed. ${ }^{\text {is }}$

The interpretive principles introduced by the Supreme Court of Canada attempt to overcome the limitation of existing precedent on treaties. It is up to the interpreting judge to determine how these new premises fit into the evidence of a case. One of the fatal weaknesses of the Canadian judicial system has been its failure to apply uniformly these interpretive principles. The reason for this failure has been that these principles are the converse of the ordinary rules of interpreting legislation and private documents; thus, they do not fit easily into Anglo-Canadian judicial consciousness.

The purpose of this article is to explore the interpretative principles of sui generis treaties introduced by the Supreme Court of Canada since the repatriation of the Constitution in 1982. To sustain the new constitutional order, interpreting judges must forge a new vantage point in the post-colonial era. In approaching treaties in the constitutional context, courts must reconsider treaty rights from the point of view of the treaty parties, rather than from the assumptions of sovereignty from above or the fiction of Parliamentary sovereignty ${ }^{16}$ that have been the traditional components of constitutional interpretation. This article will attempt to explain the new constitutional interpretative principles of the sui generis treaties.

Ibid. at 95 (para. 51); Sioui, supra note 1 at 1035-1036, $1052-62$.

to Badger, ibid. at $95-99$ (paras. 52-58).

$1 \quad$ See Sparrow, supra note 3 at $1107-08$ and $1114 ; R$ v. Taylor and Williams (1981), 34 O.R. (2d) 360 at 367 (Ont. C.A.), (taking bull frogs during closed season contrary to Ontario Game and Fish Act) [hereinafter Taylor].

12 Simon, supra note 1 at 402; Sioui, supra note 1 at 1035.

13 Badger, supra note 1 at 92,95 (paras. 41, 52); Nowegijick v. $R$, [1983] 1 S.C.R. 29 at 36 [hereinafter Nowegijick].

$14 \quad$ Badger, ibid. at 92 (para. 41); Nowegijick, ibid. at 36.

is Badger, ibid.; Simon, supra note 1 at 402, 405-06; Sioui, supra note 1 at 1035, 1061; and Mitchell v. Peguis Indian Band, [1990] 2 S.C.R. 85 at 142-43 [hereinafter Mitchell].

i6 T.R.S. Allan, "Parliamentary Sovereignty: Lord Denning's Dexterous Revolution" (1983) 3 Ox. J. Leg. St. 22; G. Winterton, "The British Grundnorm: Parliamentary Supremacy Re-examined" (1976) 92 L.Q. Rev. 591. 


\section{Indian TREATY RightS AS CONSTITUTIONAL RightS}

The existing aboriginal and treaty rights of the aboriginal peoples of Canada are hereby recognized and affirmed.... The Constitution of Canada is the supreme law of Canada, and any law that is inconsistent with the provisions of Constitution is, to the extent of the inconsistency, of no force of effect. ${ }^{17}$

The Constitution Act, 1982 recognizes and affirms existing treaty rights as part of the supreme law of Canada. Section 35(1) did not introduce a new idea into the law. ${ }^{18}$ It merely reaffirmed the principle of fidelity to the Crown's promises in the Constitution of Canada. ${ }^{19}$

This respect for the Crown's promises is part of the aristocratic code of honour, and is imposed by the Crown on the courts and on the law officers of the Crown. ${ }^{20}$ The promise principle is the foundation of constitutional law in England and Canada. In treaty law, the principle asserts that nations may impose on themselves obligations where none existed before. The international standard has always been that every treaty must be performed by the parties in "pacta sunt servanda" or in good faith. ${ }^{21}$ The promise principle is a preemptive norm of treaty interpretation that protects treaty compliance. Similar principles have been extended to individuals and legal entities in private contractual law. ${ }^{22}$

Section 35 of the Constitution Act, 1982 closed the constitutional cycle that began with the sui generis treaties. These treaties have been called the hidden constitution of Canada. ${ }^{23}$ From 1693 to 1930 , they provided an innovative means of political alliance between Aboriginal nations and the imperial Crown. ${ }^{24}$ They produced a distinctive

Sections 35(1), 52(1), Constitution Act, 1982, being Schedule B to the Canada Act 1982, (U.K.) 1982, c. 11, Schedule B in Part II, entitled "Rights of the Aboriginal Peoples of Canada." For interpretation of the Constitution of Canada, see Reference re Manitoba Language Rights (1985) 19 D.L.R. (4th) 1 at 20-24 [hereinafter Manitoba Reference] ("This court cannot take a narrow and literal approach to constitutional interpretation. The jurisprudence of the court evidences a willingness to supplement textual analysis with historical, contextual and purposive interpretation in order to ascertain the intent of the makers of our Constitution" (at 24).

Section 35(1) states: "The existing aboriginal and treaty rights of the aboriginal peoples of Canada are hereby recognized and affirmed."

19 The promissory basis of the treaties is illustrated by the Sioui case, supra note 1, where the Supreme Court of Canada concluded that a British military officer's document with the Huron Nation was a treaty.

20 H.V. Evatt, The Royal Prerogative (Sydney: Law Book, 1987) at 246ff.

21 Vienna Convention on the Law of Treaties, 23 May 1969, U.N. Doc. A/CONF.39/27 at 289 (1969), 1155 U.N.T.S. 331 art. 26 [hereinafter Vienna Convention]; Case Concerning Rights of Nationals of the United States in Morocco, [1952] I.C.J. Reports 176 at 212.

22 See C. Fried, Contract as Promise: A Theory of Contractual Obligation (Cambridge, Mass.: Harvard University Press, 1981) at 1.

23 B. Slattery, "The Hidden Constitution of Canada: Aboriginal Rights in Canada" (1984) 32 Am. J. of Comp. L. 361.

24 As Lord Dorchester stated in 1791 to the First Nations: "The King's right with respect to your territory were against the Nations of Europe.... But the King never had any rights against you but to such parts of the country as have been fairly ceded by yourselves with your own free consent by public convention and sale." Archives Ontario, Simcoe Papers, Letterbook at 17-1791 as cited in B. Clark, Native Liberty, Crown Sovereignty: The Existing Right of Self-Government in Canada 
federalism $^{25}$ that protected the worldview, languages, and political autonomy of the Aboriginal nations from the immigrants, and they gave the imperial Crown the authority and legitimacy to govern the immigrants. Ultimately they gave the immigrants the right to exercise governance in Canada.

Under the general constitutional and statutory rule of British and Canadian law, the last expression of the imperial Crown governs any conflict in earlier law. ${ }^{26}$ In s. 35(1), in the last act of imperial authorities over Canada, the imperial Crown and Parliament reaffirmed the treaty order and rights. Thus, s. 35(1) began the post-colonial constitutional era by confirming Aboriginal and treaty rights as part of the supreme law of Canada.

The purpose of s. 35(1) was to remedy the failure of the courts to respect treaties as constitutional documents. ${ }^{27}$ Canadian courts have failed to recognize that the sui generis treaties created constitutional rights that secured to the Aboriginal peoples their inherent rights, as well as explicit delegations of obligations to the imperial Crown and all its agents. In Sparrow, the Supreme Court of Canada concluded that "[f]or fifty years after the publication of Clement's The Law of the Canadian Constitution (3rd ed. 1916), there was a virtual absence of discussion of any kind of Indian rights." 28 During this era treaties were falsely assumed not to be imperial covenants of trust, obligations, and rights, but malleable devices of statecraft or bureaucratic memoranda of understandings that were frequently to be ignored. ${ }^{29}$ Section 35 strengthens the long-standing constitutional protection of treaty rights in British law that was virtually ignored in Canadian precedent. It represents a constitutional check on unilateral action by Canadian governments ${ }^{30}$ and limits the enormous power wielded by the Canadian state over the oppressed Aboriginal peoples.

The Supreme Court of Canada found that the wording of s. 35(1) of the Constitution Act, 1982 provides a framework for the constitutional analysis of existing Aboriginal and treaty rights. ${ }^{31}$ Section $35(1)$ gives both rights constitutional status and priority, and sanctions treaty challenges to social and economic policy objectives embodied in general federal or provincial legislation to the extent that treaty rights are affected. ${ }^{32}$ The Supreme Court has held that "both Aboriginal and treaty rights possess in common a unique sui generis nature." ${ }^{n 3}$ In each, the honour of the Crown is engaged through its relationship with the Aboriginal peoples. ${ }^{34}$ Additionally, the Supreme Court of

(Montreal: McGill-Queen's University Press, 1990) at 80.

J.Y. Henderson, "Empowering Treaty Federalism" (1995) 58 Sask. L. Rev. 241.

P. Hogg, Constitutional Law of Canada, 3d ed. (Toronto: Carswell, 1992) at 14-15.

Ibid. at 686-687. E.g., see infra notes 135-139 and text.

Sparrow, supra note 3 at 1103.

Royal Commission Volume 1, supra note 1 at 248.

R. v. Howard, [1994] 2 S.C.R. 299, Gonthier J. [hereinafter Howard].

Badger, supra note 1 at 106 (para. 79).

Ibid. at 105 (para. 78).

Ibid. at 105 (para. 77), citing Guerin v. R, [1984] 2 S.C.R. 335 at 382; Simon, supra note 1 at 404.

Badger, ibid. at 105 (para. 78), citing Dickson C.J.C. and La Forest J. in Sparrow, supra note 3 at 1110 . 
Canada has held that the phrase "recognized and affirmed" creates a constitutional fiduciary obligation. ${ }^{35}$ The phrase affords constitutional protection to existing rights against provincial and federal legislative power as a "restraint on the exercise of sovereign power"36 and requires that a strict justification test be met.

The history of the prerogative treaties and their relationship to existing Aboriginal rights in s. 35(1), however, urges a fundamental reconsideration of judicial interpretation of treaties and Aboriginal rights in Canada. ${ }^{37}$ The framework and definition of treaty rights are different from the framework and definition of Aboriginal rights, and they should be treated differently. The Supreme Court of Canada noted that "[t]here is no doubt that Aboriginal and treaty rights differ in both origin and structure." ${ }^{138}$ Treaty rights are derived from the context of Aboriginal order. Aboriginal rights flow from the customs and traditions of Aboriginal order. ${ }^{39}$ Treaty rights are those rights on which agreement could be reached between the imperial Crown and Aboriginal nations. The English version of these agreements is written in the treaties. ${ }^{40}$ "Treaties are analogous to contracts, albeit of a very solemn and special, public nature. They create enforceable obligations based on the mutual consent of the parties." 41 Unwritten customary rights or conventions have never had a similar sanctity in British common law. ${ }^{42}$

At the time of the enactment of the treaties, both parties shared a belief in the sacred nature of the promises they exchanged. Among the Aboriginal nations, this concept was expressed in ecological terms and translated in English as "as long as the Sun and Moon shall endure,"43 "as the sun goes round, and the water flows,"44 "as long as

Ibid. The full Court said: "[W]e find that the words 'recognition and affirmation' [in s. 35(1)] incorporate the fiduciary relationship referred to earlier and so import some restraint on the exercise of sovereign power" (at 1109).

36 Sparrow, supra note 3 at 1109.

37 Badger, supra note 1 at 104-105 (para. 73).

$38 \quad$ Ibid. at 105 (para. 76).

39 Compare with the Court's analysis in $R$ v. Van der Peet, [1996] 4 C.N.L.R. 177 [hereinafter Van $\operatorname{der}$ Peet]; $R$ v. Adams, [1996] 4 C.N.L.R. 1 [hereinafter Adams]; and $R$ v. Côté, [1996] 4 C.N.L.R. 26 [hereinafter Côté].

4) Badger, supra note 1 at 92 (para 41.)

"I Ibid. at 105 (para. 76). But as Wilson J. in dissent had stated in Horseman, supra note 1 at 907, Indian treaties should not be "undermined by the application of the interpretive rules we apply today to contracts entered into by parties of equal bargaining power."

42 In Sparrow, supra note 3 at 1099, where the Court held that if the Crown wished to establish that an aboriginal right was not existing in 1982, such that it was not "recognized and affirmed" by s. 35(1), the Crown would have to show that the intention to extinguish the aboriginal right was clear and plain.

43 Mikmaw Grand Chief Tomas Denny, 25 June 1761, Treaties of Peace and Friendship with Mirimechi, Jediack, Pogmouch, and Cape Breton Micmacs at Halifax, Public Archives of Nova Scotia, Record Group 1, vol. 37, doc. 14.

44 Mawedopenais, the principal spokesman for the Ojibway Nation in Treaty 3, as recorded in English in A. Morris, The Treaties of Canada with the Indians of Manitoba and the North-West Territories, Including the Negotiations on Which They Were Based, and other Information Relating Thereto (Toronto: Belfords, Clarke, 1880) at 59 [hereinafter Morris]. 
the sun rises over our head," and "as long as the water runs." 45 For the full court, Lamer J. (as he the was) stated in Sioui: "It must be remembered that a treaty is a solemn agreement between the Crown and the Indians, an agreement the nature of which is sacred." ${ }^{46}$ The court in Badger also stated that a treaty represents an exchange of solemn promises between the Crown and the various Indian nations. It is an agreement whose nature is "sacred." 47

The sanctity of treaty promises has long been recognized in English law. As J. Chitty writes: "Nor can the King legally disregard or violate the articles on which the country is surrendered or ceded; but such articles are sacred and inviolable, according to their true intent and meaning." ${ }^{48}$ Chitty adopted this principle from the leading British case, Campbell v. Hall, ${ }^{49}$ where Lord Mansfield held that "the articles of capitulation upon which the country is surrendered, and the articles of peace by which it is ceded, are sacred and inviolable according to their true intent and meaning." ${ }^{50}$ This is a higher standard than the existing "good faith" standard in international and Canadian law. Indeed, the extraordinary sanctity of the treaties is unusual in English and Canadian law, where it is commonplace for subsequent legislation to extinguish prior rights.

In the text of the treaties, this concept was translated into the peace and good order clause of the Victorian treaties, where the Chiefs solemnly promised and engaged to strictly observe the treaty, and promised and engaged that they would in all respects obey and abide by the law. ${ }^{51}$ Typically the text describes the duration of the treaty order and rights as "forever." 52 Treaty Commissioner Morris's personal account of the negotiations emphasized the perpetual commitment:

I told you that what I was promising was not for today or tomorrow only, but should continue as long as the sun shone and the river flowed. My words will pass away and so will yours, so I always write down what I promise, that our children may know what we said and did. Next year I will send copies of what is written in the treaty, printed on skin, so that it cannot run out or be destroyed, and one shall be given to each Chief so that there may be no mistakes. ${ }^{33}$

Cree Chief Mis-lah-wah-sis at Treaty 6. Ibid. at 213 ("will last as long as the sun shines and the river runs"). Supra note 1 at 92 (para. 41 ); see supra note 5. J.D. Chitty, A Treatise on the Law of the Prerogative of the Crown: and the Relative Duties and Rights of the Subject (London: Joseph Butterworths \& Son, 1820) at 29 [emphasis added]. (1774) 1 Cowp. 204 (affd in Secretary of State, infra note 54). See Article 50 of Act of Capitulation of Montreal, 1760 in Sioui, supra note 1 at 1062 (Capitulation shall be inviolably executed). 26 June 1756, in E.B. O'Callaghan, ed., Documents Relative to the Colonial History of the State of New York, 11 vols., (Albany: Weed, Parson, 1853-1861) vol. 7 at 140 (renewing the "sacred engagements" with the King of England, and "your union ... inviolable \& lasting as the great lights of Heaven and the immovable Mountains). treaties in R.A. Reiter, The Law of Canadian Indian Treaties (Edmonton: Juris Analytica, 1995) at Part III. Morris, supra note 44 at 208, 213. 
In $R$. v. Secretary of State, ${ }^{54}$ Lord Denning articulated the sacred and inviolable standard in a modern secular, constitutional context. He found that the transfer of treaty obligations from the imperial Crown to the Crown in Right of Canada in the Canada Act, 1982 carried with it the duty to solemnly respect treaty rights and obligations. He stated:

It seems to me that the Canada Bill itself does all that can be done to protect the rights and freedoms of the aboriginal peoples of Canada. It entrenches them as part of the Constitution, so that they cannot be diminished or reduced except by the prescribed procedure and by the prescribed majorities.... [T] rights and freedoms have been guaranteed to them by the Crown - originally by the Crown in respect of the United Kingdom - now by the Crown in respect of Canada but, - in any case, by the Crown. No Parliament should do anything to lessen the worth of these guarantees. They should be honoured by the Crown in respect of Canada "so long as the sun rises and the river flows." That promise must never be broken."

His decision reinforces the role of Canadian courts in ensuring no diminishment of treaties or treaty rights. The Canadian courts have a duty to ensure they give the sui generis treaties unwavering respect.

Prior to 1982, the overwhelming mentality of Canadian legislators and courts was that they could terminate or abrogate a treaty with a First Nation by legislation. ${ }^{56}$ Under the new constitutional order, it is clear that this belief was an erroneous one. As Cory J. commented in Badger:

The NRTA only modifies the Treaty 8 right. Treaty 8 represents a solemn promise of the Crown. For the reasons set out earlier, it can only be modified or altered to the extent that the NRTA clearly intended to modify or alter those rights. The Federal government, as it was empowered to do, unilaterally enacted the $N R T A$. It is unlikely that it would proceed in that manner today. The manner in which the NRTA was unilaterally enacted strengthens the conclusion that the right to hunt which it provides should be construed in light of the provisions of Treaty $8 .{ }^{37}$

R. v. Secretary of State, [1981] 4 C.N.L.R. 86 at 127 (Eng. C.A.) [hereinafter Secretary of State]. Jbid. at 99.

Indian treaties have been held to be sources of law that produce rights which the federal legislature can modify or cancel, but not provincial legislatures. ( $R$ v. Daniels, [1968] S.C.R. 517 at 521 , Cartwright C.J.C.; $R$ v. Sikyea, [1964] S.C.R. 642 [Treaty 11] [hereinafter Sikyea]). See K. McNeil, Indian Hunting, Trapping and Fishing Rights in the Prairie Provinces of Canada (Saskatoon: Native Law Centre, 1983). These decisions assert the treaties as governed strictly by British law, not a law compatible with both nations. In British constitutional traditions, any act of Parliament could be repealed by a subsequent act, thus they assumed that Aboriginal treaties could be amended or extinguished by subsequent federal statute or agreements. Other judges consider that such instruments are a matter of honour between Canada and the First Nations, thus a moral obligation ( $R$ v. George, [1966] S.C.R. 267, [hereinafter George] (1827 Treaty); compare with Guerin, supra note 33).

Badger, supra note 1 at 105 (para. 72), 107 (para. 84). 
In Badger, the Supreme Court found that s. 1 of the Constitution Act, $1930,{ }^{58}$ a binding imperial statute, ${ }^{59}$ did not extinguish the treaties, nor did it merge and consolidate the treaties. ${ }^{60}$ There was no clear and plain intention of the Sovereign or strict proof by the Crown of the fact of extinguishment of a treaty right. ${ }^{61}$ Indian treaties are part of the prerogatives of the Crown. ${ }^{62}$ They are a distinct source of authority independent of the parliamentary government of the United Kingdom or Canada. Neither the prerogative of the imperial Crown nor the treaties with the United Kingdom are mentioned or referred to in s. 1. Thus the Constitution Act, 1930 does not effect or bind them. As McLachlin J. stated in New Brunswick Broadcasting Co. v. Nova Scotia (Speaker of the House of Assembly): ${ }^{63}$ "It is a basic rule, not disputed in this case, that one part of the Constitution cannot be abrogated or diminished by another part of the Constitution." 64

Under these rules of interpretation, and without express mention or reference of modification of the treaty, reviewing courts cannot presume any extinguishment or abrogation or diminishment of treaty rights by later imperial or constitutional acts, much less by ordinary legislation. It is helpful to remember that these different sources

Section 1 of the Constitution Act, 1930 provides: "The agreements set out in the Schedule to this Act are hereby confirmed and shall have the force of law notwithstanding anything in the Constitution Act, 1867, or any Act amending the same, or any Act of the Parliament of Canada, or in any Order in Council or terms or conditions of union made or approved under any such Act as aforesaid."

Badger, supra note 1 at 94 (para. 47).

Sopinka J. dissenting in Badger, ibid. at 84 (para. 12), also provides support for the position that constitutional provisions enacted later in time are not to be read as impliedly amending the earlier enacted provisions. Also see Estey J.'s comment in Reference Re, Bill 30, An Act to Amend the Education Act (Ont.), [1987] 1 S.C.R. 1148 at 1207.

61 Sparrow, supra note 3 at 1009 . Also see s. 17 of the federal Interpretation Act that provides: "No enactment is binding on Her Majesty or affects Her Majesty or Her Majesty's rights or prerogatives in any manner, except as mentioned or referred to in the enactment." In a treaty case not involving a constitutional question, the Court in Simon, supra note 1 clearly established that the onus is on the party arguing that the treaty has terminated to show the circumstances and events indicating it has been extinguished. This burden can only be discharged by strict proof, as Dickson C.J.C. said: "Given the serious and far-reaching consequences of a finding that a treaty right has been extinguished, it seems appropriate to demand strict proof of the fact of extinguishment in each case where the issue arises" (at 405-406).

62 Foreign Jurisdiction Act, 1890, (U.K.), 53 \& 54 Vict., c. 37; Lord Hailsham, ed., Halsbury's Laws of England, 4th ed., vol. 6 (London: Butterworths, 1977) at paras. $801-807$ [hereinafter Halsbury's] and Constitution Act, 1867, (U.K.), 30 \& 31 Vict., c. 3 (formerly The British North America Act, 1867), ss. 132 and 129. In Mitchell, supra note 15 at 109, Dickson C.J.C. acknowledges the separation of the prerogative treaty order from provincial federalism in the United Kingdom and Canada. See Badger, supra note 1 at 92 (paras. 41-42); Horseman, supra note 1 at 376; Sioui, supra note 1 at 1061; Simon, supra note 1 at 405-06. [1993] 1 S.C.R. 319.

Ibid. at 373, 390. An international treaty right or obligation remains valid in the intemational legal order and imposes international obligations upon the contracting parties, even if it has not been implemented by domestic legislation, infra note 66. Hence, the Supreme Court of Canada has held that federal government is responsible under international law for any breach of these obligations (Re Ownership of Offshore Mineral Rights of British Columbia, [1967] S.C.R. 792; Canada (Attorney General) v. Ontario (Attorney General) (Labour Convention case), [1937] A.C. 326 at 348; and Bitter v. Secretary of State, (1944) 3 D.L.R. 482, at 497. 
of imperial law were merged into the supreme law of Canada at exactly the same time and with the same authority. ${ }^{65}$

If treaty rather than Aboriginal rights are involved, an interpreting justice must be aware of the constitutional presumption against reading any treaty provision according to standards developed after the treaty and against interpreting their provisions as an abandonment of Aboriginal sovereignty or rights. ${ }^{66}$ Thus, courts have held that non-use of a treaty right does not extinguish or modify the right. ${ }^{67}$

The concept of a sacred treaty makes it impossible for reviewing courts to conclude that treaty rights can be extinguished without the consent of the Indians concerned. For example, since the Huron had the capacity to enter into a treaty with the British, they must be the only ones who can give the necessary consent to its extinguishment. ${ }^{68}$ If an existing treaty right is changed or modified, under the fiduciary obligation this taking of a vested or accrued right requires compensation.

In the new constitutional order, Canadian justices must reconsider the understandings, norms, and practices that guided the treaty making process from the point of view of both the Aboriginal nations and the British. They can no longer rely solely on the English interpretation of treaty rights provisions. In Sparrow, the court emphasized the importance of context and a case by case approach to s. $35(1) .^{69}$

In s. 35, the Supreme Court of Canada rejected the rules of the old colonial legal regime and created new interpretative principles to be applied to the treaties. Under the old rules, the Court stated that it was not in a position to question an unambiguous decision on the part of the federal government to modify its treaty obligations. ${ }^{70}$

Section 52(1) of Constitution Act, 1982, supra note 17. See Hogg, supra note 26 at 8-11.

See Case Concerning Elettronica Sicula S.p.A. (ELSI) United States of America v. Italy), [1989] I.C.J. Rep. 15, (1989) 28 I.L.M. 1109 at 1128 (para. 64), 1141 (para. 124) (intemational law different legal realm than domestic law). This follows international law where the traditional legal presumption is against any implied relinquishment of State sovereignty. Polish War Vessels, P.C.I.J. Series A/B, No. 43 (1931) at 142; The River Oder Commission, P.C.I.J. Series A, No. 23 (1929) at 26; S.S. "Lotus," P.C.I.J. Series A, No. 10 (1927) at 18; Polish Postal Service, P.C.IJ. Series B, No. 11 (1925) at 39; S.S. "Wimbledon," P.C.I.J. Series A, No. 1 (1923) at 24-25.

Taylor, supra note 11 at 360 .

Sioui, supra note 1 at 1063. For vested or accrued rights compare, $R$ v. Mercure, (1988) 48 D.L.R. (4th) 1 at 55-58 [hereinafter Mercure], La Forest J. for the majority ("I begin with the well-established principle that statutes are not to be read as interfering with vested rights unless the intention is declared expressly or by necessary implication" (at 55)), $\operatorname{Re}$ Lefebvre and The Queen (1982), 69 C.C.C. (2d) 448 at 463 (Alta. Q.B.), aff'd 34 C.C.C. (3d) 349 (Alta. C.A.); Spooner Oils Ltd. v. Turner Valley Gas Conservation Bd., [1933] S.C.R. 629 at 638, Duff C.J.C.; Main and Stark (1890), 15 App. Cas. 384 at 388 (P.C.); E.A. Driedger, The Construction of Statutes, 2d ed. (Toronto: Butterworths, 1983) at 183-85. See also FPC v. Tuscarora Indian Nation, 362 U.S. 99 at 131-32 (1960), Black, Warren, and Douglas JJ. dissent on issues that majority did not reach (consent may be a prerequisite to abrogation); Minnesota v. Hitchcock, 1185 U.S. 373 (1902), (consent requirements); First National Bank v. United States, 59 F. 2d 367, 368 (8th Cir. 1932) (treaty rights can only be extinguished with tribal consent).

Badger, supra note 1 at 99 (para. 58).

Sikyea and George, supra note 56; and $R$ v. Moosehunter, [1981] I S.C.R. 282 at 293. 
Canadian courts must now examine the broader constitutional significance of Crown promises in the treaties, understood in the context in which they were negotiated and concluded by both parties. These interpretive principles force an interpreting court into comparative legal theory and systems.

\section{Contextual ANalysis of Indian Treaties}

These treaties were the product of negotiation between very different cultures and the language used in them probably does not reflect, and should not be expected to reflect, with total accuracy each party's understanding of their effect at the time they were entered into. This is why the courts must be especially sensitive to the broader historical context in which such treaties were negotiated. They must be prepared to look at that historical context in order to ensure that they reach a proper understanding of the meaning that particular treaties held for their signatories at the time.

Wilson J., dissenting (Dickson C.J.C. and L'Heureux-Dube J., concurring) in Horseman"

Most interpretations of written documents begin with an analysis of the text. The Supreme Court of Canada has found, however, that reviewing courts cannot begin with the presumption that the text of the Indian treaties manifests a shared communication between the treaty parties. ${ }^{72}$ Instead, the Supreme Court requires an interpreting judge to put treaties into their proper historical and legal context. The interpreting judge must look at the conditions and circumstances that are relevant to a treaty and at the structure of the treaty process. In Sioui ${ }^{73}$ Lamer J. acknowledged and confirmed that reviewing judges "must take into account the historical context and perception each party might have as to the nature of the undertaking contained in the document under consideration." ${ }^{74}$

Eurocentrism makes contextual analysis inherently problematic. J.M. Blaut argues that Eurocentrism is the belief that European civilization has some unique quality derived from race, culture, environment, mind, or spirit that makes Europeans permanently superior to all other communities. It is this assumption of superiority that lies at the core of European diffusionism, the belief that it is the destiny of Europeans to impose their civilization on other cultures around the world. ${ }^{75}$

Horseman, supra note 1 at 907.

See discussion below at Part IV.

Sioui, supra note 1 at 1045, quoting Norris J. in R. v. White and Bob (1964), 50 D.L.R. (2d) 613 (B.C.C.A.), affd [1965] S.C.R. vi. [hereinafter White and Bob]. Nowegijick, supra note 13, affirmed the same principle that Indian instruments with the Crown must be construed in light of the law and fact contemporary to them as part of the law of Canada. For elements of a historical context, see Taylor, supra note 11 at 120.

74 Ibid. at 1035; Simon, supra note 1 at 402 . The context of this statement was in the issue of determining if a document could legally be considered a treaty. In $R$. v. Sikyea, (1964) 43 D.L.R. (2d) 150 at 158 (N.W.T.C.A.) [hereinafter Sikyea (C.A.)], Johnson J.A. of the Northwest Territory Court of Appeal struggled with this issue. Hall J. stated that Johnson J.A. had dealt with the important issues fully and correctly in their historical and legal settlings (Sikyea, supra note 56 at 646).

J.M. Blaut, The Colonizer's Model of the World: Geographical Diffusionism and Eurocentric History (New York: Guilford Press, 1993) at 8-12. 
In Eurocentric thought, contexts are neither static nor neutral; they are constantly modified to rationalize changing regimes of European thought. Eurocentric contexts are created for the specific purpose of understanding events and law in another time and culture; however, these contexts have no equivalent in Aboriginal thought or language. To assume that an Aboriginal context can be adequately explained by a Eurocentric context is the essence of cognitive imperialism and of the academic process that underlies colonization.

Professor Roberto Unger of Harvard Law School asserts that contexts are either natural or artificial. If a context allows people to move within it to discover everything about the world they can discover, he labels it a natural context. If a context does not allow one to discover everything in the world, Unger labels it an artificial context. ${ }^{76}$ Under Unger's definition, the contexts scientists use to explain the world are natural contexts, whereas the contexts historians, social scientists, and legal scholars use to explain history, social systems, and legal thought are artificial contexts.

For example, Thomas Kuhn has explained the intellectual transformations in sciences that attempt to understand the natural order of the world using the concept of "paradigms."77 Periodically in science, certain natural phenomena are observed that cannot be explained by the basic assumptions or postulates of the established science. These phenomena are often called anomalies. Eventually, someone proposes new fundamental postulates to explain the anomaly. These new postulates create the substance of a new scientific paradigm. Paradigm shifts in the history of science, from the Copernican to the Newtonian, and the Newtonian to the Einsteinian, are interpretations of an explanation crisis. In contrast to the natural contexts of science, which allow one to discover everything in the world, are the artificial contexts of history, law, and social theory.

Unger asserts three theses of the modernist account of artificial contexts. The first thesis is the principle of contextuality itself. Contextuality is the belief that all modern thought is conditional because it derives from assumptions and desires that are not questioned but are taken as given. The second thesis is the idea of progress. All artificial contexts can be revised, but such activity is exceptional and transitory. The third thesis is the implicate continuity of progress. Empowering ideas that make one

R.M. Unger, Social Theory: Its Situation and Its Task. A Critical Introduction to Politics, a Work in Constructive Social Theory (Cambridge: Cambridge University Press, 1987) at 18-25 [hereinafter Social Theory]. In regard to law or jurisprudence, a context may be roughly described as the study of lawyers' fundamental assumptions, an explanatory or argumentative structure that an ordinary legal inquiry takes for granted.

T. Kuhn, The Structure of Scientific Revolutions (Chicago: University of Chicago Press, 1970). A paradigm, for my purposes, is a set of shared conceptions held by any academic or professional community concerning what is possible. It is a configuration that defines an inquiry, the metaphysical assumptions, the unquestioned terminology, the common questions, the modes of reasoning, the specific theories, and the applications. It is a set of implicit assumptions, concepts, theories, and postulates held in common by several members of a community, which enables them to explore jointly a well-defined and delimited area of inquiry and to communicate in a specialized language about the subject. These paradigms define the boundaries of acceptable inquiry and the limiting assumptions within a discipline. 
explanatory or society-making practice better than another can supplement or revise established contexts, but the conditionality of an artificial context is relatively immune from revision. ${ }^{78}$ For example, as the eighteenth-century German philosopher Hegel demonstrated, the history of European thought and culture is a changing pattern of great liberating ideas that inevitably turn into suffocating oppression and domination. ${ }^{79}$ Another example is that none of the great revolutions or renaissances in European law ever succeeded in abolishing the prerevolutionary law; instead, the new legal orders transformed the legal tradition while remaining within its original context. ${ }^{80}$

Unger argues that artificial contexts are arbitrarily chosen and are often forced on people, who then play by the rules. Since artificial contexts are not natural but are created by human desires for particular purposes, they need to be justified. Often these justifications borrow assumptions from a natural context to make the argument that the artificial context is based on higher-order laws and principles, thus lending the artificial context the semblance of objectivity. The new interpretive principles attempt to give reviewing courts new insights and methods to understand artificial, man-made contexts.

The contextual approach to Indian treaty interpretation is a complicated analytical process that involves two different ways of thinking about the world. Contextual analysis takes place on two main levels: historical and legal. It is important for an interpreting justice to consider both the historical and the legal context from the point of view of each party to the treaty, and to eliminate colonial or racial bias when evaluating these contexts. This means that using the existing historical and legal contexts of Eurocentric and Aboriginal thought, an interpreting judge must create a broad and generous interpretation in favour of Aboriginal thought. This process is contrary to the method previously used by historians and justices to interpret historical contexts, which viewed Indian treaties as anomalies ${ }^{81} 1$ or sui generis phenomena. ${ }^{82}$

\section{Ibid.}

G.W.F. Hegel, The Phenomenology of Mind, trans. J.B. Baiilie (New York: Macmillian, 1910); R.M. Unger, Knowledge and Politics (New York: Free Press, 1975) at 1 [hereinafter Knowledge and Politics].

See P. Fitzpatrick, The Mythology of Modern Law (London: Routledge, 1992); A. Carty, "Introduction: Post-Modern Law" in A. Carty, ed., Post Modern Law: Enlightenment, Revolution and the Death of Man (Edinburgh: Edinburgh University Press, 1990); H.J. Berman, Law and Revolution: The Formation of the Western Legal Tradition (Cambridge, Mass.: Harvard University Press, 1983).

81 See generally, F.P. Prucha, American Indian Treaties: The History of A Political Anomaly (Berkeley: University of California Press, 1994). See Marshall C.J.'s comment in Cherokee Nation v. Georgia (1831), 2 Pet. 16 [hereinafter Cherokee Nation] ("The condition of the Indians in relation to the United States is perhaps, unlike that of any other two people in existence.... The relations of the Indians to the United States is marked by peculiar and cardinal distinction which exist nowhere else").

Guerin, supra note 33 at 342, 387, per Dickson J.; Sparrow, supra note 3 at 1112 per Dickson C.J.C. and La Forest J. These rights cannot be fitted into categories drawn from English or French law. 


\section{A. Historical Contexts}

Many complexities exist for justices who seek to understand the historical contexts of Indian treaties. ${ }^{83}$ An appeal to history creates the impression of being impartial, of applying objective rules rather than subjective policy or personal values. ${ }^{84}$ Few discussions exist on the use of history in constitutional interpretation, ${ }^{85}$ although many problems exist around the constitutional interpretation of treaty rights under s. 35(1).

Most historians and lawyers assume that the statements they make about the past are valid if there is adequate evidence to support them. Four assumptions about reality and knowledge have guided the European search for truth. They are (i) that the world exists and has existed independently of any beliefs about it; (ii) that perceptions, under certain conditions, provide an accurate impression of reality; (iii) that reality is structured according to most of the concepts of the language Europeans use to describe it; and (iv) that existing rules of inference are a reliable means of arriving at new truths about reality. ${ }^{86}$ Since humans have no access to reality independent of their beliefs about and experiences of it, the truth of these four assumptions cannot be proved, as European philosophers have been tireless in explaining. ${ }^{87}$

The assumptions that have guided the European search for truth are of questionable value in reconstructing the historical context of Aboriginal treaties. ${ }^{88}$ First and foremost, there are important differences in the way Aboriginal and European languages relate to the world and life. These differences create an absence of shared communication, of which it is important for an interpreting judge to be aware when he or she attempts to create a mutual historical context.

For centuries, philosophers and linguists have debated the question of how much of our consciousness of cognitive reality comes from the structure and habits of the languages we speak. ${ }^{89}$ For those who believe in a universal underlying structure of

See W. Hildebrandt \& S. Carter, "The Historical Canon and Elder Evidence," Treaty 7 Elders $e t$ al., The True Spirit and Original Intent of Treaty 7 (Montreal \& Kingston: McGill-Queen's University Press, 1996) [hereinafter Treaty 7 Elders]; Royal Commission Volume 1, supra note 1 at 31-33; G.E. Sioui, For an Amerindian Autohistory: An Essay on Foundations of a Social Ethic (Montreal \& Kingston: McGill-Queen's University Press, 1992); R. Price, ed., The Spirit of the Alberta Indian Treaties (Montreal: Institute for Research on Public Policy, 1979); R. Fumoleau, As Long as This Land Shall Last: A History of Treaty 8 and Treaty 11, 1870-1939 (Toronto: McClelland and Stewart, 1986).

K.E. Swinton, The Supreme Court and Canadian Federalism: The Laskin-Dickson Years (Toronto: Carswell, 1990) c. 4, "History in Constitutional Interpretation." Ibid.

86 C.B. McCullagh, "Introduction: Truth and Justification," in Justifying Historical Descriptions (New York: Cambridge University Press, 1984) especially at 1-3.

I Ibid. at 2 .

ss J.Y. Henderson, "Governing the Implicate Order: Self-Government and the Linguistic Development of Aboriginal Communities" in Proceedings of the Conference of the Canadian Centre for Linguistic Rights (Ottawa: University of Ottawa, 1995) 285 [hereinafter The Implicate Order]; Treaty 7 Elders, supra note 83.

89 See D.H. Alford, "A Hidden Cycle in the History of Linguistics" (1980) 4 Phoenix: New Directions in Its Study of Man Nos. 1 \& 2. 
grammar (and write in English), whose modern spokespersons include Noam Chomsky and Joseph Greenberg, the answer is that language has a minimal effect on worldview. These scholars argue that all languages have much in common, although how they know this globally remains unclear. ${ }^{90}$ For those interested in the relativity of grammars, including anthropological linguists such as Edward Sapir and Benjamin Whorf ${ }^{91}$ (who studied Aboriginal peoples), the differences between languages and ways of speaking, thinking, perceiving, and being, are more interesting and important than the commonalties, and these scholars assert that language and worldview reciprocally influence each other in a hermeneutic spiral. Between these two views, many mediating positions exist.

Contemporary scholars such as Sapir and Whorf view worldview and language as active shapers of ideas and creators of arbitrary classification systems. They closely relate cognitive reality and language. For them, language facilitates the modification of objective reality ${ }^{92}$ and has the power to evoke new categories and complex ideas. As James Britton writes: "The object and events of the world do not present themselves to us already classified. The categories into which they are divided are the categories which we divide them." ${ }^{93}$

This recognition has led some modern scholars to "reinterpret" our past and to assert that they cannot view Eurocentric history as the progressive intuiting of nature, but rather as the exteriorizing of a certain way of looking at things. Cognitive categories and ideas emerge gradually and become defined in language. These categories in turn affect patterns of speech and the suggestive values of words. Linguistic habits influence perception and experience, and the word world of artificial contexts becomes the way we arrange and interpret objective reality. People assume the world is organized according to the structure and categories of the language they speak, and they fail to see evidence that is not consistent with the linguistic categories with which they are familiar. ${ }^{94}$

Aboriginal language and modes of inference are oriented around process rather than around objects. ${ }^{95}$ This is reflected in the language, which is verb-based rather than noun-based. In comparing Aboriginal languages with the English language in terms of

See N. Chomsky, Language and Mind (New York: Harcourt Brace Jovanovich, 1972) at 76. J.B. Carroll, ed., Language, Thought, and Reality: Selected Writings of Benjamin Lee Whorf (Cambridge: MIT Press, 1956) [hereinafter Language, Thought, and Reality].

"Language is more than a mere means of communication, it is part and parcel of the identity and culture of the people speaking it. It is the means by which individuals understand themselves and the world around them." Mahe v. Alberta, [1990] 1 S.C.R. 342 at 362 per Dickson C.J.C. See also Ford v. Quebec (A.G.), [1988] 2 S.C.R. 712 (no distinction between message and medium); Mercure, supra note 68 at 57 per La Forest J. (language as fundamental rights, which has been treated as being of an almost constitutional nature); Manitoba Reference, supra note 17 (language rights ground in role it plays in structure and order the world around us).

J. Britton, "The Development of Writing Abilities," School Council (Great Britain), in Project of the Written Language of 11 through 18 years old (London: MacMillan, 1973) at 23.

See generally S. Langer, Philosophy in a New Key; A Study in the Symbolism of Reason, Rite, and Art, 3d ed. (Cambridge: Harvard University Press, 1957).

The Implicate Order, supra note 88 at 295-301, see especially 297-98. 
noun-based values, scholars have emphasized three distinct features of Aboriginal languages in America. ${ }^{96}$ Aboriginal languages make a distinction between real and imaginary nouns; they do not individualize and fragment mass nouns or give form to them (for example, they do not specify or measure intangibles); and they treat time as being continuous with little difference in the tenses of verbs. In contrast, the English language uses the same linguistic, spatial, and metaphoric structure for real and imaginary nouns; constantly tries to give form to intangibles and mass nouns (for example, a glass of water); and has a fragmented and objectified concept of time, which is divided into the three dimensions of past, present, and future. ${ }^{97}$

How should an interpreting justice reconcile the divergent way Aboriginal peoples organize reality outside the Eurocentric tradition of rational discourse? Historical context in British thought is based on causal explanations, which are always accounts of the relationship between events in linear time. Historical context in Aboriginal thought is based on the notion of interrelated cycles of events. Unlike the noun-oriented European consciousness, the verb-oriented Aboriginal consciousness is not concerned with sequence or necessity. Since everything is related and linked in circular causation, it is difficult to isolate relationships of cause and effect, key facts, or ultimate causes. ${ }^{98}$ These marked differences in worldviews make it necessary to consider whether modern historians or lawyers can depend on in existing historical descriptions of the Aboriginal past or of Indian treaties.

Judicial use of any historical material is not without problems. ${ }^{99}$ Justices face a problem with sources, their probative value in constitutional interpretation, and the issue of the historians' judgment. These problems are accentuated in treaty interpretation when the only available evidence is written historical records created by the European colonialists. When attempting to define historical contexts, an interpreting justice must be aware of the assumptions lying behind historical contexts and of the challenges of understanding the Aboriginal historical context. Interpretation requires understanding two divergent worldviews and languages and exercises more analytical skills than the existing multicultural analysis required by the Charter. ${ }^{100}$ For example, MacKinnon J.A. stated in Taylor that in determining the effects of the treaties, it is important to

M.R. Haas, Language, Culture, and History (Stanford: Stanford University Press, 1978) at 37; Language, Thought and Reality, supra note 91 at 147-52.

S. Chawla, "Linguistic and Philosophical Roots of Our Environmental Crisis" 18 Environmental Ethics 253.

See generally Royal Commission Volume 1, supra note 1 at 32-36.

See generally C. Berger, The Writing of Canadian History (Toronto: Oxford University Press, 1976).

Section 27 of Canadian Charter of Rights and Freedoms, Part I of the Constitution Act, 1982, being Schedule B to the Canada Act 1982 (U.K.), 1982, c. 11 [hereinafter Charter] ("This Charter shall be interpreted in a manner consistent with the preservation and enhancement of the multicultural heritage of Canadians"). See $R$ v. Big M Drug Mart Lid., [1985] 3 W.W.R. 481 at 519 (S.C.C.). 
consider the history and oral traditions of the tribes concerned and the surrounding circumstances at the time of the treaty relied on by the parties. ${ }^{101}$

Based on Taylor, ${ }^{102}$ the historical context the court found relevant in the treaty formation in Sioui was "(a) continuous exercise of a right in the past and at present; (b) the reasons why the Crown made a commitment; (c) the situation prevailing at the time the document was signed; (d) evidence of a relation of mutual respect and esteem between the negotiators; and (e) the subsequent conduct of the parties." The analysis is flawed, however, since it entirely ignores the reason the Aboriginal nations chose to make a commitment to the Crown. It creates an interpretative monopoly of one treaty party over the other. Moreover, the use of the subsequent conduct of parties violates the principle that a treaty must be interpreted in light of fact and laws existing at the time the treaty was entered into.

The lack of consideration given to Aboriginal context in the court's analysis reflects standard practice in historical studies and analysis in Canada. Canadian historical studies have either ignored the Aboriginal perspective or treated it as a background element to the European context. ${ }^{103}$ In particular, most Canadian histories accept and project European categories and values as universal, an issue I will return to later. ${ }^{104}$

Existing historical and anthropological writings on Aboriginal peoples are fallible because they were written by European visitors, traders, and guests to Aboriginal Canada, who lived in a cognitive solitude separate from the Aboriginal worldview and language. These newcomers may have shared a space with the Aboriginal peoples, but they never shared the same context. They could observe and describe within their own context what the Aboriginals did, and they could speculate about why the Aboriginal peoples did certain things, yet the actual working of the Aboriginal worldview or context was usually incomprehensible to them. ${ }^{105}$ This makes these works interesting mixtures of imagination and description.

A proper analysis of historical contexts must seek to understand Aboriginal knowledge and Euro-Canadian knowledge, and where possible to unite these distinct

Taylor, supra note 11 at 364. See also C. McLeod, "The Oral Histories of Canada's Northern People, Anglo-Canadian Evidence Law, and Canada's Fiduciary Duty to First Nations: Breaking Down the Barriers of the Past" (1992) 30 Alta. L. Rev. 1276.

lbid.

103 For an introduction to these problems, see M.E. Turpel, “Aboriginal Peoples and the Canadian Charter: Interpretive Monopolies, Cultural Differences" in R. Devlin, ed., Canadian Perspectives on Legal Theory (Toronto: Montgomery Edmond, 1991) 506; P. Monture-Angus, Thunder in My Soul: A Mohawk Woman Speaks (Halifax: Fernwood Publishing, 1995) at 131-52; J.R. Ponting, Arduous Journey: Canadian Indians and Decolonization (Toronto: McClelland and Stewart, 1986); P. Moynihan, "The Decolonization of Modern Law: Dismantling the Relations between Race and Law" (1993) 8:2 Can. J. of L. \& Soc'y 191; The Native American Struggle: Conquering the Rule of Law: A Colloguium (1993) 20 N.Y.U. Rev. of L. \& Social Change 199; R.N. Clinton, "Redressing the Legacy of Conquest: A Vision Quest for a Decolonized Federal Indian Law" (1993) 46 Ark. L. Rev. 77.

105 The Implicate Order, supra note 88 at 285-316. 
ways of knowing. If a unified view is impossible, a proper analysis should state this truth, rather than impose one knowledge system on the other. Most historical contexts are not without ambiguity, and a court that relies on the records of the past to the detriment of the Indians must justify its choices. For a positive example of historical interpretation, Dickson C.J.C. in Mitchell v. Peguis Indian Band stated:

In the context of this appeal, the aboriginal understanding of "the Crown" or "Her Majesty" is rooted in pre-Confederation realities. The recent case of Guerin took as its fundamental premise the "unique character both of the Indians' interest in land and of their historical relationship with the Crown." (at p. 387 S.C.R. [p. 139 C.N.L.R.] emphasis added.) That relationship began with pre-Confederation contact between the historic occupiers of North American lands (the aboriginal peoples) and the European colonizers (since 1763, "the Crown"), and it is this relationship between aboriginal peoples and the Crown that grounds the distinctive fiduciary obligation on the Crown. On its facts, Guerin only dealt with the obligation of the federal Crown arising upon surrender of land by Indians and it is true that, since 1867, the Crown's role has been played, as a matter of the federal division of powers, by Her Majesty in right of Canada, with the Indian Act representing a confirmation of the Crown's historic responsibility for the welfare and interests of these peoples. However, the Indians' relationship with the Crown or sovereign has never depended on the particular representatives of the Crown involved. From the aboriginal perspective, any federal-provincial divisions that the Crown has imposed on itself are internal to itself and do not alter the basic structure of Sovereign-Indian relations. This is not to suggest that aboriginal peoples are outside the sovereignty of the Crown, nor does it call into question the divisions of jurisdiction in relation to aboriginal peoples in federal Canada. ${ }^{106}$

Another example is the dissenting opinion of Wilson $\mathrm{J}$. in Horseman, cited at the beginning of this section, who restated the reasoning behind the interpretative principles. ${ }^{107}$

\section{B. Legal Context}

Judicial construction of the context of the treaties can have more than one perspective. One perspective may be the context or source of law at the time the parties were formulating the treaty. This perspective attempts to determine the meaning of the treaties to the parties at the time the treaties were made. Another possible perspective is to apply the modern context to a dispute around the meaning of the text. This perspective is an attempt to make the past conform to the present. The resulting reading of treaties in this perspective meshes not only two languages, but also at least two times, two places, and two interpretations. ${ }^{108}$

In its interpretive principles, the Supreme Court of Canada requires that an interpreting judge must liberally construe the terms of the Indian treaties in the light of

Mitchell, supra note 15 at 108; see also R. v. Horse, [1988] I S.C.R. 187, 202, 203 [hereinafter Horse].

Horseman, supra note 1 at 907 . Compare to Horse, ibid. at 201, Howard, supra note 30, and Eastmain Indian Band v. Canada (Federal Administrator), (1992), (1993) I F.C. 501, leave to appeal to Supreme Court of Canada refused [1993] 3 S.C.R. vi [hereinafter Eastmain], where context was not used.

R. Scholes, Protocols of Reading (New Haven: Yale University Press, 1989) at 7. 
the law existing at the time the various parties signed the treaty. ${ }^{109}$ Indian treaties "must be given the effect the signatories obviously intended them to have at the time they were entered into the treaties, even if they do not comply with to-day's formal requirements." 10 Such analysis requires an attempt to understand both legal orders at the time the treaties were entered into. In international law, this interpretative principle is called the rule of intertemporal law. ${ }^{\prime \prime}$

This interpretative context raises intriguing questions about Aboriginal order and laws. In the past, most courts have ignored the customs and ceremonies of the Aboriginal lex loci. ${ }^{112}$ It was argued that Aboriginal peoples had no law, ${ }^{113}$ and that all law is found in statutes or written legal instruments. The inclusion of Aboriginal rights in s. 35(1) of the Constitution Act, 1982 has put an end to this issue. ${ }^{114}$

The existence of Aboriginal orders and rights is a foundation of the treaties. ${ }^{115}$ Aboriginal promises and peaceful alliances created the great Aboriginal federations. ${ }^{116}$ The idea of the sanctity of spoken sounds imposing vital and living relationships, freedoms, and obligations where none existed before is based on a distinct Aboriginal worldview. Such promises were seen as a manifestation of a spiritual realm. It was this worldview that created the prerogative treaties. The path of the Aboriginal peoples to the treaties was different from the path taken by the Europeans, and their understanding of the promises and treaties would also have been different. ${ }^{117}$ Aboriginal nations entered into the treaties as the keepers of a certain place, whereas most European nations entered into the treaties to acquire jurisdiction over a foreign territory. ${ }^{118}$

In British and Canadian law, all treaties begin their life in constitutional obscurity and indeterminacy. ${ }^{119}$ Treaties are not acts of the imperial Parliament. They are

See Case Concerning Right of Passage over Indian Territory Portugal v. India, [1960] I.C.J. Rep. 6 [hereinafter Right of Passage]. This is consistent with the use of historical context in construing legislation. To interpret a statute, words are taken in the sense which they bore at the time when the statute was passed, and they are not affected by matters subsequent. $R$. v. L. (1922), 51 O.L.R. 575 at 580 per Riddel J; Sioui, supra note 1 at 1044-45; Nowegijick, supra note 13 at 29.

Wilson J. in Horseman, supra note 1 at 907.

Ibid.

A few cases deal with Aboriginal customary law, e.g., Connolly v. Woolrich (1867), 17 R.J.R.Q. 75 (Que. S.C.) 151; Calder v. British Columbia (A.G.) (1973) S.C.R. 313; Roberts v. Canada (1989), 1 S.C.R. 335. See B. Slattery, "Understanding Aboriginal Rights" (1987) 66 Can. Bar Rev. 727 at 738-39; N.K. Zlotkin, "Judicial Recognition of Aboriginal Customary Law in Canada: Selected Marriage and Adoption Cases" [1984] 4 C.N.L.R. 1.

$R$ v. Delgamuukw, [1993] 5 W.W.R. 97 (B.C.C.A.).

Royal Commission on Aboriginal Peoples, Partners in Confederation; Aboriginal People, Self-Government, and the Constitution (Ottawa: Minister of Supply and Services, 1993) at 8-9, 19-21; and Treaty Making in the Spirit of Co-existence: An Alternative to Extinguishment (Ottawa: Minister of Supply and Services, 1995).

Henderson, "Empowering Treaty Federalism," supra note 25 at 246-69.

Ibid. at 251-63.

Implicate Order, supra note 88.

Royal Commission Volume 1, supra note 1 at 128-32.

A. Jacomy-Millette, Treaty Law in Canada (Ottawa: University of Ottawa Press, 1975). 
organic, constitutional agreements, created by the prerogatives of the imperial Crown. ${ }^{120}$ Prerogative treaties have been found to have the force of law by themselves, ${ }^{121}$ and there are no written limits to the powers of the imperial Crown to conclude treaties. Professor Bruce Wildsmith, in a careful analysis of the judgments of the Supreme Court of Canada in Simon, Sioui, and Horseman, has isolated the fundamental assumptions of the legal context of the sui generis treaties:

...based on certain assumptions about the relationship between the parties. These assumptions are not well articulated in the preparatory discussions or the final documents signed. Indeed, thus far treaty litigation has not progressed to the point where these fundamental assumptions have played a key role. Yet some of these assumptions have been articulated in a fragmented way in seminal cases such as Horseman and Sioui ... certain assumptions underlie the treaty process and that the treaties arguably incorporate by implication these assumptions. The conduct of the parties before, during and subsequent to the signing of the treaties also reflect these assumptions. These assumptions are:

1. The aboriginal parties to the treaties were regarded by the Crown as discrete, cohesive entities, i.e., "nations" enjoying a measure of independent autonomy. They could decide whether to sign treaties or not. Their internal integrity was unaffected by the treaty process.

2. The aboriginal parties had, before signing treaties, a measure of external sovereignty, and so the form of relationship with the Crown could be described as a "nation-to-nation alliance." Subject to the specific terms of the treaties, a like relationship existed after signing the treaties, although the capacity to maintain alliances and nation-to-nation relations with other European states might be diminished, especially where treaties recognized the sovereignty of the Crown.

3. Subject to the specific terms of the treaties, the aboriginal parties had after as well as before signing internal sovereignty, i.e., "autonomy in their internal affairs." The conduct of the Crown towards the aboriginal parties before, during and after the execution of the documents unequivocally demonstrates this: the Crown did not presume to interfere in internal aboriginal affairs.

4. The treaties were the product of consultation and negotiation and purported to be based on the co-operation and consent of the aboriginal societies. They were intended to clarify aspects of the relationship between the aboriginal societies and the Crown, but the treaties did not purport to deal with all aspects of the relationship between the parties. They as well do not purport to be imposed against the will of the aboriginal nations. Aboriginal consent was necessary to form treaties; aboriginal consent was necessary to terminate treaties.

The Crown approached the aboriginal societies on the basis that problems were to be solved through co-operation, negotiation and quid pro quo bargaining rather than unilateral imposition. ${ }^{122}$

The treaties placed Aboriginal nations and their territories directly under the protection of the imperial Crown. ${ }^{123}$ These unique jurisdictions became known in

121 Ritcher v. R. (1943) Ex. C. R. 64, Angers J.; Francis v. The Queen, [1956] S.C.R. 618, per Kerwin C.J.C. at 621; Secr. of St. Can. v. Alien Property Custodians for U.S. (1931), 1 D.L.R. 890 (S.C.C.) per Duff J.

B. Wildsmith, "Treaty Responsibilities: A Co-Relational Model" (1992) U.B.C. L. Rev. 324 at 328-31 [footnotes omitted].

123 
British constitutional law as foreign jurisdictions, a separate legal category from dominions and colonies. ${ }^{124}$ The imperial Parliament affirmed the separateness of the prerogative jurisdiction in the Foreign Jurisdiction Act, $1890 .{ }^{125}$ This declaratory act affirmed the continuing exercise of Her Majesty's prerogative jurisdiction under treaties of protection with Aboriginal peoples, independent of the imperial Parliament. The Act validated the treaties with the Aboriginal nations within British law. ${ }^{126}$ By making the treaties a distinct legal category, the Act immunized the treaties from the supremacy of the imperial Parliament and from all authority derived from the imperial Parliament's usual competency in the dominions and colonies or over subjects. "The act instructed the British judiciary to interpret every prerogative action performed pursuant to this unique jurisdiction as valid. ${ }^{127}$

Another aspect to the legal context that is relevant to understanding Indian treaties is the sacredness and inviolability of the treaties in British and Aboriginal law. ${ }^{128}$ The fiduciary obligations of the Crown that derive from Indian treaties are also involved in the legal context of treaty interpretation. ${ }^{129}$ The good faith standard in international and Canadian law may also be involved in certain contexts of treaty interpretation. The existing intersection and gaps in the legal regimes are also involved.

\section{Rejecting Colonial or Racial Bias in Contextual Analysis}

For a long time the courts and developing legislative bodies in Canada understood the nature and legal effects of the Indian treaties poorly. ${ }^{130}$ The failure of Parliament and the courts to respect these distinct and separate sources of rights opened the Aboriginal peoples to exploitation by governments and immigrants. ${ }^{131}$ To correct this denial of legal rights and obligations, the Constitution of Canada explicitly recognizes and affirms existing ancient customary rights of Aboriginal peoples, as well as their treaties with the imperial Crown. ${ }^{132}$

See supra note 59 and accompanying text.

See Foreign Jurisdiction Act 1890, supra note 62, and Calvin's Case (1608), 77 E.R. 377 (K.B.).

See also Thompson and Story JJ.'s dissenting opinion in Cherokee Nation, supra note 81, that stated the Cherokees composed a foreign state in the Law of Nations and within the sense and meaning of the constitution (ibid. at 49-72).

The exercise of prerogative power within foreign jurisdictions was limited in the same manner as acquisition of territories that were ceded or conquered, i.e., the doctrine of continuity of law and property. Foreign Jurisdiction Act, supra note 62 at s. 1.

Ibid., s. 3. This is a special law parallel to An Act to Remove Doubts as to the Validity of Colonial Laws (U.K.), 28 \& 29 Vict., c. 63.

Supra notes 47-57 and accompanying text; Royal Commission Volume 1, supra note 1 at 129.

See generally L.I. Rotman, Parallel Paths: Fiduciary Doctrine and the Crown-Native Relationship in Canada (Toronto: University of Toronto Press, 1996).

Halsbury's, supra note 62, vol. 18, "Treaties and International Agreements" at 918-35 (paras. 1769-1802); J. Woodward, Native Law in Canada, 1996 ed. (Toronto: Carswell, 1994) at 403-416. H. Cardinal, The Unjust Society: The Tragedy of Canada's Indians (Edmonton: Hurtig, 1969) [hereinafter Unjust Society]; and H. Cardinal, The Rebirth of Canada's Indians (Edmonton: Hurtig, 1977) [hereinafter Rebirth].

See supra note 15. 
As mentioned earlier, most source materials that can be used to establish historical and legal contexts are contaminated with colonial, religious, cultural, and racial biases. The biases of Eurocentric thought led to colonialism and racism. ${ }^{133}$ The court in Simon explicitly limits parts of the historical context by rejecting interpretations that continue colonial or racist assumptions, biases, and prejudices. ${ }^{134}$ This is a limiting principle of contextual interpretation.

In 1928, Patterson J. of the County Court of Nova Scotia in $R$ v. Syliboy rejected the legal principle of treaties with Aboriginal nations on the grounds that Aboriginals were uncivilized persons or savages. ${ }^{135}$ The Crown presented no evidence on the treaty issue at trial; however, the Judge raised the question and answered it. ${ }^{136}$

\begin{abstract}
"Treaties are unconstrained acts of independent persons." But the Indians were never regarded as an independent power. A civilized nation first discovering a country of uncivilized people or savages held such country as its own until such time as by treaty it was transferred to some other civilized nation. The savages' rights of sovereignty even of ownership were never recognized.... In my judgment the treaty of $\mathbf{1 7 5 2}$ is not a treaty at all and is not to be treated as such; it is at best a mere agreement made by the Governor and council with a handful of Indians giving them in return for good behavior food, presents and the right to hunt and fish as usual.... Having called the agreement a treaty, and having perhaps lulled the Indians into believing it to be a treaty with all the sacredness of a treaty attached to it, it may be the Crown should not now be heard to say it is not a treaty. With that I have nothing to do. That is a matter for representations to the proper authorities - representations which if there is nothing else in the way of the Indians could hardly fail to be successful. ${ }^{137}$
\end{abstract}

Patterson J. also held that Governor Hopson did not have the authority to make the treaty, since he was not specially deputized. ${ }^{138}$ Others frequently regarded Patterson J.'s reasoning as the most significant interpretative statement in this field in Canada. ${ }^{139}$

J.M. Blaut, supra note 75; R.A. Williams, The American Indian in Western Legal Thought: The Discourses of Conquest (New York: Oxford University Press, 1990); S. Amin, Eurocentrism (New York: Monthly Review Press, 1988).

Simon, supra note 1 at 399.

[1929] 4 C.N.L.C. 430, (Treaty of 1752) (Grand Chief of Mick Macks was convicted of unlawful possession of furs contrary to the Nova Scotia Lands and Forests Act,), rev'd by Simon, ibid. Syliboy, ibid. at 436.

Ibid. at 436-37, rev'd by Simon, supra note 1. Also see Sero v. Gault (1921), 4 C.N.L.C. 468, 472-73 (Ont. S.C.).

Syliboy, ibid. at 437, rev'd by Sioui, supra note 1 . See Halsbury's, supra note 62, vol. 18 at paras. 1771-72.

See L.C. Green, "Legal Significance of Treaties affecting Canada's Indians" (1972) 1 Anglo-American L. Rev. 119 at 129; for a more critical assessment of the court's obiter dicta see N.A.M. MacKenzie, "Indians and Treaties in Law" (1929) 7 Can. Bar Rev. at 561, especially at 563-68. For a similar conclusion in the international law, see Island of Palmas Case, Netherlands v. United States (1928), 2 R.I.A.A. 829 at 831 (Treaties between Native princes or chiefs and Netherlands East Indian Company "are not, in the international law sense, treaties or conventions capable of creating rights and obligations such as may, in intemational law, arise out of treaties," because the native princes or chiefs or people are not recognized as members of the community or nations, at 858), rev'd in Right of Passage case, supra note 109. See also J.Y. Henderson, "The Status of Indian Treaties in International Law" in D. Hiscox, K. Sabo, \& C. Zayid, eds., Aboriginal Rights and International Law: Proceedings of the Twenty-Second Anmual Conference, Canadian 
More than fifty years later, the Supreme Court of Canada reversed this holding in Simon. ${ }^{140}$ Dickson C.J.C., speaking for a unanimous court, held that the 1929 ruling was substantively unconvincing and a bias and prejudice of another era in Canadian law "inconsistent with a growing sensitivity to Aboriginal rights." ${ }^{141}$ This holding argues that colonialism and racism have no probative value in contextual analysis.

Prevailing popular opinion during the treaty era held that Aboriginals were representatives of a primitive "savagism" that stood in direct opposition to Eurocentric civilization. ${ }^{142}$ Popular opinion held that Aboriginal culture was destined to be obliterated as civilization progressed westward. ${ }^{143}$ For example, Norris J.A. in White and Bob attempted to bring out the importance of the historical context in treaty analysis; ${ }^{144}$ however, in so doing he exposed the continuing racial bias of the civilized European and the uneducated savage:

In view of the argument before us, it is necessary to point out that on numerous occasions in modem days, rights under what were entered into with Indians as solemn engagements, although completed with what would now be considered informality, have been whittled away on the excuse that they do not comply with present day formal requirements and with rules of interpretation applicable to transactions between people who must be taken in the light of advanced civilization to be of equal status. Reliance on instances where this has been done is merely to compound injustice without real justification at law. The transaction in question here was a transaction between, on the one hand, the strong representative of a proprietary company under the Crown and representing the Crown, who had gained the respect of the Indians by his integrity and the strength of his personality and was thus able to bring about the completion of the agreement, and, on the other hand, uneducated savages. The nature of the transaction itself was consistent with the informality of frontier days in this Province and such as the necessities of the occasion and the customs and illiteracy of the Indians demanded. The unusual (by the standards of legal draftsmen) nature and form of the document considered in the light of the circumstances on Vancouver Island in 1854 does not detract from it as being a "Treaty." 14s

Council on International Law (21-23 October 1993) (Ottawa: Canadian Council on International Law, 1993) 126.

140

141

Supra note 1.

Ibid. at 399.

See generally R.H. Pearce, Savagism and Civilization: A Study of the Indian and the American Mind (Berkeley: University of California Press, 1988); R.H. Bartlett, The Indian Act of Canada (Saskatoon: Native Law Centre, 1980).

The colonization strategy of assimilation was explicitly declared in the Civilization of Indian Tribes $A c t$, S.C. 1857 , c. 26 , while its complementary strategy of extinguishing tribal organization protected by treaties was explicitly declared in the Journal of Legislative Assembly of Canada, 11858, 21 Vict. Appendix 21, Part III. Also see the federal government's affirmation of this strategy in Act for the gradual enfranchisement of Indians and the better management of Indian Affairs, S.C. 1869, c. 6. The federal government justified these dual strategies in Canada, "Annual Report of the Indian Branch of the Department of the Secretary of State for the Provinces" No. 23 in Sessional Papers (1871). Also see generally, J. Errington, The LION, the EAGLE, and UPPER CANADA: A Developing Colonial Ideology (Montreal \& Kingston: McGill-Queen's University Press, 1987); B.W. Dippie, The Vanishing American: White Attitudes and U.S. Indian Policy (Middletown, Conn.: Wesleyan University Press, 1982). He was trying to determine whether a document falls into the category of a treaty under s. 88 of the Indian Act.

White and Bob, supra note 73 at 649. 
In interpreting the Crown's intent or actions in treaties, the Supreme Court has held that such Eurocentric attitudes are not controlling parts of the historical context.

Eurocentrism is the overarching bias in both factual and legal analysis of contexts. Eurocentric assumptions have created the modern view of what the world is really like, and how thought and language are structured. These Eurocentric prejudices come with their own set of explanations and seemingly objective verifications. ${ }^{146}$ The biased beliefs of Eurocentrism are the architects of British and Canadian scholarship. Academic disciplines, theories, and paradigms are constructed around the framework of Eurocentric diffusionism. The relentless focus of Canadian scholarship has been on the immigrant self seeking to ignore or to understand and master the Aboriginal other - both the land and the people. Diffusionism is the given that has created the dualisms of the savage and the civilized, the colonized and the colonizer, the primitive and the modern.

Nationalism is a bias integral to Eurocentric diffusionism. Immigrant nationalism was a direct by-product of British colonialism. It perpetuated the constructions of civilization and Christianity as justifications for colonializing the savage, who blocked the progress of civilization. Similar to Dickson C.J.C.'s analysis in Simon, post-colonial theory ${ }^{147}$ decolonizes legal history and the historical context by correcting the assumptions of the Eurocentric context. ${ }^{148}$ Under post-colonial analysis, the conventions of Canadian scholarship derived from British Eurocentrism no longer seem universal, fair, or neutral. They appear self-interested, subjective, and biased.

The colonial legacy makes contextual analysis an arduous task. An interpreting justice has to reconcile concepts of truth and relativity from Eurocentric thought with Aboriginal concepts of space, time, and process. The interpreting justice also has to confront problems of meaning in Eurocentric thought, as well as squabbles in British

147 Post-colonial theory is an intellectual strategy of the previously colonized Aboriginal scholars. It is a criticism that confronts the unequal process of representation by which the historical experience of the colonized Aboriginals came to be framed in Eurocentric scholarship. It seeks to end the privileged position of Eurocentrism and colonial thought in modern society and to create parity in modern thought. This step toward a just society questions the theory of European diffusionism, its assumptions about the universal features of European languages, epistemologies, and legal orders, as well as the European theories of style and genre. Aboriginal researchers and writers who seek to rise above the colonial legacies and seek to understand the meaning of Canada from an Aboriginal perspective must overcome nationalized scholarship and racial innuendo.

See L. Noël, Intolerance: A General Survey, trans. A. Bennett (Montreal \& Kingston: McGill-Queen's University Press, 1994); I. Young, Justice and the Politics of Difference (Princeton: Princeton University Press, 1990); A. Nandy, The Intimate Enemy: Loss and Recovery of Self under Colonialism (Delhi: Oxford University Press, 1983); H.A. Bulhan, Frantz Fanon and the Psychology of Oppression (New York: Plenum Press, 1985); J. Axtell, The Invasion Within: The Contest of Cultures in Colonial North America (New York: Oxford University Press, 1985); A. Memmi, Dominated Man: Notes Towards a Portrait (Boston: Beacon Press, 1969); F. Fanon, Black Skin White Mask, trans. C.L. Markman (London: MacGibbons \& Kee, 1968); F. Fanon, The Wretched of the Earth, preface by Jean-Paul Sartre, trans. Constance Farrington (London: MacGibbon \& Kee, 1965); A. Memmi, The Colonizer and the Colonized, trans. Howard Greenfield (New York: The Orion Press, 1965). 
and Eurocentric historiographic writings. ${ }^{149}$ Awareness of this dilemma is the first step in contextual analysis.

The second step in contextual analysis, the attempt to construct Aboriginal contexts, is harder. To construct Aboriginal contexts, worldviews, and legal orders without the interference of British Eurocentrism requires a transformation of judicial consciousness. The interpreting judge must attempt to reconstruct historical and legal contexts while standing outside the English language, its laws and hegemony, its partial disciplines and hidden structures.

The interpretative principles of contextual analysis require an interpreting justice to understand the creative manifestations of Aboriginal contexts at the time of entering the particular treaty. Frequently, this Aboriginal context is not developed in legal theory or history. ${ }^{150}$ Thus the interpreting justice must rely on ancient teachings and knowledge, most of which are still undocumented and unwritten.

Eurocentric records and historical legal contexts have ignored this part of Canadian history. Most often these materials rely on the British and French language and archives, and have a colonial, racial, and national bias. ${ }^{151}$ Because of the Europeans' vast interpretative monopoly, these materials are of no utility in understanding Aboriginal contexts and teachings. Indeed, the Eurocentric materials often conflict with the Aboriginal teachings. Historians and anthropologists have long recognized the difficulties of reconstructing Aboriginal histories, ${ }^{152}$ and most do not have unified standards for interpreting legal documents or for resolving conflicts.

The third step in contextual analysis is for the interpreting judge to formulate an equitable synthesis of Aboriginal and Eurocentric contexts. In Taylor, MacKinnon J.A. stated the traditional judicial view:

Although it is not possible to remedy all of what we now perceive as past wrongs in view of the passage of time, nevertheless it is essential and in keeping with established and accepted principles that the courts not create, by remote, isolated current view of past events, new grievances. ${ }^{133}$

$149 \quad$ See Berger, supra note 99.

iso E.g., Treaty 7 Elders, supra note 83.

131 E.g., W. Daugherty, The Maritime Treaties in Historical Perspective (Ottawa: Department of Indian Affairs, 1983); and O.P. Dickason, "Amerindians Between French and English in Nova Scotia, 1713-1763" (1986) 10 American Indian Culture and Research Journal 31.

See B. Trigger, Children of Aataentsic: A History of the Huron People to 1660 (Montreal: McGill-Queen's University Press, 1976) at 5-26; and Natives and Newcomers: Canada's "Heroic Age" Reconsidered (Montreal \& Kingston: McGill-Queen's University Press, 1985) at 164-72; and "Early Native North American Responses to European Contact: Romantic versus Rationalistic Interpretations" (1991) Journal of American History 1213.

153 Taylor, supra note 11 at 364 . E.g. in Sikyea, supra note 56, the reviewing justice stated: "It is always to be kept in mind that the Indians surrendered their rights in the territory in exchange for these promises. This 'promise and agreement' like any other, can, of course, be breached, and there is no law of which I am aware that would prevent Parliament by legislation, properly within s. 91 of the B.N.A., from doing so" (at 646). 
Judicial reform was required by constitutional reform and is slowly developing. In Sparrow, the Supreme Court affirmed that "the context of 1982 is surely enough to tell us that this is not just a codification of the case law on aboriginal rights that had accumulated by 1982."154 Likewise, in another context, Brennan J. of the Australian High Court commented in the landmark decision in Mabo v. State of Queensland:

If it were permissible in past centuries to keep the common law in step with international law, it is imperative in today's world that common law should neither be nor seen to be frozen in an age of racial discrimination. ${ }^{155}$

\section{Furthermore, Professors Peter Hogg and Mary Ellen Turpel suggest:}

Constitutional lawyers and elected officials must review those [constitutional] doctrines that reflect the Eurocentric bias of Canadian constitutional law and government ... and reorder institutions and doctrine so as to give full expression to the longstanding Aboriginal presence in Canada. ${ }^{156}$

These insights are an integral part of the new interpretative context of sui generis Indian treaties.

\section{INTENT OF the Treaty Parties}

I cannot too strongly urge the necessity of making them [the Indians] throughly [sic] acquainted with its [the treaty] provisions, before regarding it as being finally concluded, as I have already said, every head of a family has more or less to say regarding the affairs of the community and means should be adopted to make the tribe at large conversant with every article of the agreement to be entered into. If this is done and if the Indians with the general assent of the tribe enter into a Treaty after thoroughly understanding it, they will I am confident adhere to it most faithfully. If on the other hand, they did not understand it circumstances might arise in carrying it out which would lead them to suppose they were overreached and in that case it would not be worth the parchment on which it was written.

Memorandum concerning Instructions to Victorian Treaty Commission, $1870^{157}$

The complexities of contextual analysis are continued in the analysis of intent. In many cases the dividing line between contextual and intentional analysis is unclear. Contextual analysis appears to be about discovering events and legal regimes, whereas intentional analysis is concerned with cognitive attributes and the intelligibility of human conduct. Historical materials have been used to determine the meaning of a constitutional document through evidence of the intent of those involved in its design and through existing statutes of the time. ${ }^{158}$

Sparrow, supra note 3 at 1106.

(1988) 83 A.L.R. 14 at 19 [emphasis added].

P.W. Hogg \& M.E. Turpel, "Implementing Aboriginal Self-Government: Constitutional and Jurisdictional Issues" (1995) 74 Can. Bar Rev. 187 at 192.

S.J. Dawson, Dawson Report, 18 December 1870 at 145, PAC Microfilm Reel b510, M.G. 11, Colonial Office 42, Vol. 698, Dispatch 5357, 17 May 1871 at 123-148; Order-in-Council, 30 April 1875, PAC: Black Series, RG 10, No. 124-2.

Swinton, supra note 84 at $99,117-19$. 
The Supreme Court of Canada has yet to confront the complex issues of reliability that inevitably accompany understanding the intent of two distinct parties. Before 1982, few justices attempted to establish any common linguistic understanding of the intent of treaty or constitutional documents or statutes. ${ }^{159}$ Since constitutional reform, however, the Supreme Court has held that reviewing judges must interpret realistically the intent of both treaty parties at the time of the signing of the treaty. ${ }^{160}$ The Court has established that the original intent of the treaty parties is controlling in modern interpretation. ${ }^{161}$ The intent of each is an essential and unique part of the supreme law of Canada. ${ }^{162}$

The principle of understanding the intent of the treaty parties places an interpreting judge at the crossroads of conflicting worldviews, languages, and methods as well as dual legal systems. The principle also requires unique legal sources and authorities for resolving these disputes. ${ }^{163}$ The interpretive principles authorize extrinsic or external evidence for finding and effectuating the intent of the treaty parties. Judicial reliance on archival evidence is questionable, however, since archival records are biased toward Eurocentric theories of causation, and are incomplete, ambiguous, and unreliable about Aboriginal intent. The records of treaty interpreters and commissioners often fail to provide clear answers to modern questions, and the reports of the treaty commissions are unreliable as neutral or objective sources of information about mutual intent. ${ }^{164}$ They speak to the intent of the treaty commissioners, but not to the intent of the imperial Crown.

No explicit principles or methods appear to have guided interpretation at treaty negotiations (or travaux préparatoires) or when the texts of the treaties were drawn up in English. In most situations, interpreting judges have no or little evidence of the understandings or ideas that shaped how the treaty interpreters or translators went about

Ibid. at 109-10, See Reference re s. 94(2) of the Motor Vehicle Act, [1985] 2 S.C.R. 486 when Lamer J. admitted the Minutes of the Proceedings and Evidence of the Special Joint Committee on the Constitution, but held that they should be given little weight in the interpretation of the Charter of Rights (at 553-54). Compare to use of intent in Sioui, supra note 1 at 1043-1061; Sparrow, supra note 3 at 1099: "The test of extinguishment to be adopted, in our opinion, is that the Sovereign's intention must be clear and plain if it is to extinguish an aboriginal right"; see Simon, supra note 1, in Judson J.'s view this was what had occurred in Calder, supra note 112 where, as he saw it, a series of statutes evinced a unity of intention to exercise a sovereignty inconsistent with any conflicting interest, including aboriginal title; Hall J. in that case stated (at 404) that "the onus of proving that the Sovereign intended to extinguish the Indian title lies on the respondent and that intention must be 'clear and plain'; $R$ v. Strongquill (1953), 8 W.W.R. (N.S.) 247 at 269 , McNiven J.A. (It is also a cardinal rule of interpretation that words used in a statute are to be given their common ordinary and generally accepted meaning. Statutes are to be given a liberal construction so that effect may be given to each Act and every part thereof according to its spirit, true intent and meaning.) Sioui, supra note 1 at 1069, 1070, 1071; Simon, supra note 1 at 401. Parliament to Alter or Replace Senate (1979), 102 D.L.R. (3d) 1 at 13 (S.C.C.). Napoleon, [1986] 1 C.N.L.R. 86 (B.C.C.A.). 
their work. Yet, while subsequent conduct surrounding the signing of the treaties by both parties may reflect common intent and lead to an understanding of a particular text, ${ }^{165}$ it has been held that subsequent conduct cannot be used to alter the unambiguous terms of the documents. ${ }^{166}$

In determining the intent of the Crown in making treaties, the separation of authority under British constitutional law is vital. The parliaments of the United Kingdom and Canada were never parties to treaty negotiations or the signing of treaties. Lord Denning has ruled that s. 35(1) of the Constitution Act, 1982 transferred the treaty obligations of the imperial Crown to Canada. ${ }^{167}$ Many reviewing judges in Canada have slipped into the nationalistic assertion that Canada entered into the treaties with the Aboriginal nations, ${ }^{168}$ and often they attempt to assert the intent of the federal government as equal to that of the imperial treaty commissioners. These assertions are contrary to the legal context of the treaties. Canadian constitutional law never authorized the federal parliament to enter into treaties with the Aboriginal nations, ${ }^{169}$ and the federal government was never a party to the treaties. At best, the federal government is a third-party administrative agent of treaty obligations. ${ }^{170}$ The subsequent action of the federal government or its administrative agencies cannot shed light on the Crown's intent in making the treaties.

Under the interpretative principles, as part of his or her constitutional analysis of treaty rights, an interpreting judge is required to determine the intent of the Aboriginal nations. ${ }^{171}$ If an interpreting judge insists on sticking close to the Crown intent, he or she deprives the grantors of the treaties of their intent. The goal of the interpreting judge should be to discover an equitable standard in the constitutional order; he or she needs a method of comprehending the reciprocal subjectivities of intent and a means to make sense of them.

Taylor, supra note 11 at 365 ; Bartleman, ibid. at 91.

166 Horse, supra note 106 at 201; Sioui, supra note 1 at 1049.

167 Secretary of State, supra note 54.

168 E.g., Badger, supra note 1 at 90 (para. 39) (number treaties concluded between federal government and various Indian bands between 1871-1923).

169 At the time the Chiefs and Headmen of Victorian treaties, in 1876, reached the treaty with the United Kingdom, the imperial Crown was the only entity in Canada who had power to make treaties (Hogg, supra note 26). The common law accorded to the imperial Crown full power to conduct foreign affairs (ibid. at 282). At the time of Victorian treaties, the Canadian Parliament played no necessary role in the making of treaties, as treaties were one of the exclusive prerogatives of the imperial Crown (ibid. at 284 and 1-17). Subsequently Canada acquired an international personality in its own right, and the treaty-making powers were gradually distributed to the federal Crown by the Letters Patent in 1947, R.S.C. 1985, Appendix II, No. 31 (ibid. at 282-83).

See s. 91 (peace order and good government) and ss. 91(24) and 132 of the Constitution Act, 1867, supra note 62.

17. Sioui, supra note 1 at 1049-50 (to indicate the parties' intent to enter into a treaty, the Court was offered evidence to present a picture of the historical context of the period); Simon, supra note 1 at 401 ("In my opinion, both the Governor and the Micmac entered into the Treaty with the intention of creating mutually binding obligations which would be solemnly respected"). 
Most Aboriginal peoples have distinct understandings of intent and causation that differ from Eurocentric views. ${ }^{172}$ To disregard these understandings is to neglect an integral part of the intent for which a judicial account is required. If an interpreting judge disregards Aboriginal intent, he or she risks losing sight of what is peculiar in the grantors' will. Courts are no longer free to disregard Aboriginal interpretations of the world and, in particular, of the treaties. The dilemma is that no supralinguistic or universal human consciousness exists, thus the intent of each treaty party must be ascertained within its own worldview.

Interpreting judges will seldom know anything about Aboriginal language, intent, or causation. They cannot substitute what seems to be a reasonable intent for the actual intent of the Aboriginal parties, since this would be contrary to the interpretive principles. English, with its structure of desire and purpose, is inadequate when it comes to understanding Aboriginal intent. Thus, judges must understand the intent of an Aboriginal party from the structure of Aboriginal language.

Aboriginal concepts of intent are enfolded in their languages and oral traditions. Usually elders refer to these concepts in English as the "spirit and intent" of the treaties. The Aboriginal perspective originates with the ancestors' promises to and alliance with the keepers of other life forms. These promises and alliances are the foundations of the Aboriginal relationship with the environment.

Other problems in determining Aboriginal intent include the fact that the treaties are not comprehensive documents or codes of Indian rights. They are partial agreements that reflect only what the treaty parties could agree upon. Those powers not expressly delegated to the Crown are reserved to the Aboriginal order. ${ }^{173}$ Another problem is that existing historical material and oral evidence shed little light on Aboriginal expectations at the time of the treaties. In Horseman, Wilson J. wrote:

While one must obviously be sensitive to the fact that contemporary oral evidence of the meaning of provisions of Treaty No. 8 will not necessarily capture the understanding of the treaty that the Indians

See generally H.C. Wolfart \& J.F. Carroll, Meet Cree: A Practical Guide to the Cree Language (Edmonton: University of Alberta Press, 1973) [hereinafter Meet Cree]. An example of an Algonquian complex notion of causality is the Coeur d'Alene language of Idaho. Whorf stated that they have, "instead of our simple concept of 'cause', founded on our simple 'makes it (him) do so,' [a] grammar [that] requires its speakers to discriminate (which of course they do automatically) among three causal processes, denoted by three causal verb-forms: (1) growth, or maturation of an inherent cause, (2) addition or accretion from without, (3) secondary addition, i.e., of something affected by process 2 . Thus, to say 'it has been made sweet,' they would use form 1 for a plum sweetened by ripening, form 2 for a cup of coffee sweetened by dissolving sugar in it, and form 3 for griddle cakes sweetened by syrup made by dissolving sugar. If, given a more sophisticated culture, their thinkers erected these now unconscious discriminations into a theory of triadic causality, fitted to scientific observations, they might thereby produce a valuable intellectual tool for science. WE could imitate artificially such a theory, perhaps, but we could not apply it, for WE are not habituated to making such distinctions with effortless ease in daily life." Language, Thought, and Reality, supra note 91 at 266. 
had in 1899 , in my view such evidence is relevant where it confirms the archival evidence with respect to the meaning of the treaty. ${ }^{174}$

Thus, construing the shared intent of the treaties is a complex issue. It is clear that both parties had an intent to establish a lasting relationship. ${ }^{175}$ The purpose and nature of this relationship is less clear. The Aboriginal intent was to extend the hand of friendship to the imperial Crown and to protect the Aboriginal way of life and livelihood. ${ }^{176}$ To the Crown's consciousness, such protection brought the Aboriginal nations and their lands within the jurisdiction of the United Kingdom. The imperial Crown needed the treaties to justify its jurisdiction in North America to other nations. These respective intents provide a conceptual scheme in which to elucidate the spirit of the relationship. The treaties secured the peace and friendship of the Aboriginal nations and the Crown. They prevented the harassment of settlers and other nations by the Aboriginal nations, and they protected the Aboriginal nations from harassment and disruption of their traditional way of life and livelihood. Further, the treaties provided for the sharing of land and territory between the Aboriginal nations and settlers on certain conditions.

\section{A. Protection of the aboriginal Way of Life}

Before the treaties, both treaty parties were distinct nations. Only the express will of the Aboriginal Chiefs, Headmen, or treaty delegates could change this position through consensual treaties. The intent and terms of the treaties make it clear that the Aboriginal nations chose to place themselves under the protection of the imperial Crown on certain conditions. There is no evidence of any intent to place Aboriginal order or government under the authority of any British government or institution.

The Crown's promise to protect the Aboriginal way of life is integral to the context of the treaties. ${ }^{177}$ Protection included maintaining Aboriginal order in the lands protected by the Crown's jurisdiction. The Aboriginal nations placed their territory under the protection of a foreign Crown and in return the Crown promised, among other things, to maintain Aboriginal government. Thus a unique and innovative protective relationship emerged in British and international law. ${ }^{178}$ The treaties were not gifts or grants from the Crown, nor were they policy decisions of the Aboriginal nations.

\footnotetext{
$174 \quad$ Horseman, supra note 1 at 911.

175 Sioui, supra note 1 at 1044.

176 Royal Commission Volume 1, supra note 1 at $175-76$

17 For implementation of treaty obligations, see $A n A C t$ for the better protection of Lands and Property of the Indians in Lower Canada, S.C. 1850, c. 42; An Act for the protection of the Indians in Upper Canada from imposition, and the property occupied or enjoyed by them from trespass and injury, S.C. 1850, c. 74. The federal Indian Act, S.C. 1876, c.18, consolidated the existing federal obligations and colonization strategies in eastern Canada and the new treaty relations with the First Nations in the North-West Territories (Bartlett, supra note 142 at 4-5, 19). E.g., Sioui, supra note 1 at 1053-55.
} 
Since the affirmation of existing treaty rights in the Canadian Constitution in 1982, the Supreme Court of Canada, in Sioui ${ }^{179}$ and in Badger, ${ }^{180}$ has acknowledged and recognized the treaties of the imperial Crown with various Aboriginal nations. The Court has interpreted the prerogative treaties as constitutive documents. ${ }^{181}$ In construing the 1760 treaty with the Huron Nation, for example, Lamer J., speaking for the unanimous Supreme Court of Canada in Sioui, ${ }^{182}$ concluded:

[W]e can conclude from the historical documents that both Great Britain and France felt that the Indian nations had sufficient independence and played a large enough role in North America for it to be good policy to maintain relations with them very close to those maintained between sovereign nations. The mother countries did everything in their power to secure the alliance of each Indian nation and to encourage nations allied with the enemy to change sides. When these efforts met with success, they were incorporated in treaties of alliance or neutrality. This clearly indicates that the Indian nations were regarded in their relations with the European nations which occupied North American as independent nations. ${ }^{183}$

In Badger, Cory J. stated: "[I]t must be remembered that a treaty represents an exchange of solemn promises between the Crown and the various Indian nations." 184

The sui generis treaties were negotiated compacts at the highest levels of the law in the United Kingdom, and none of the imperial acts or treaty obligations between the Aboriginal nations and the Crown was more integral to the compacts than the obligation of protection. ${ }^{185}$ Seeking to maintain the Aboriginal way of life and livelihood was one part of the overarching intent of the Aboriginal Chiefs and Headmen in the treaty negotiations. ${ }^{186}$ The official reports of the treaty commissioners made it clear that the intent of the treaties was not to interfere with the traditional Aboriginal

Ibid. at 1063.

Supra note 1 at 92 (para. 41).

Simon, supra note 1 at 410 and Sioui, supra note 1 at 1061-66. In the United Kingdom, according to Lord McNair, the Courts dealt with initial treaties made with native tribes "in the same way as they would have dealt with a treaty with a foreign state" (Law of Treaties 1961:54). See also H. Reiff, "The Proclaiming of Treaties in the United States" (1936) A.J.I.L. 63 at 67-69.

Supra note 1.

lbid. at 1052-53.

Badger, supra note 1 at 92 (paras. 41 and 78); see Sioui, supra note 1 at 1063; Simon, supra note 1 at 401.

See The Royal Proclamation (7 October 1763), reprinted in R.S.C. 1985, App. II, No. 1 [hereinafter Royal Proclamation]; Treaty of 1760, infra note 198. Also see F.S. Cohen, Handbook of Federal Indian Law (Washington, D.C.: U.S. Government Printing Office, 1942) at 122; Felix S. Cohen's Handbook of Federal Indian Law, R. Stirickland et al., eds. (Charlottesville: Mitchie, 1982).

E.g., Badger, supra note 1 at 90 (para. 39), $97-99$ (paras. 55-57) ("The promise that this livelihood would not be affected was repeated to all the bands who signed the treaty"). 
way of life. ${ }^{187}$ The Indian elders also stressed the importance of maintaining the traditional Aboriginal way of life and livelihood. ${ }^{188}$ In Badger, Cory J. stated:

[I]t is clear that for the imperial Crown guarantee to the Indians that they could continue their aboriginal rights of hunting and fishing rights to earn their livelihood was the essential element which led to their signing the treaties. ${ }^{189}$

The Supreme Court of Canada has also made it clear that the "protectorate relationship" did not extinguish Aboriginal sovereignty; neither did it abolish Aboriginal order or governmental powers, or make them dependent upon federal law. Lamer J. in Sioui cited a statement made by the Supreme Court of the United States about British policy toward the Indians in the eighteenth century:

\begin{abstract}
Such was the policy of Great Britain towards the Indian nations inhabiting the territory from which she excluded all other Europeans; such her claims, and such her practical exposition of the charters she had granted: she considered them as nations capable of maintaining the relations of peace and war; of governing themselves, under her protection; and she made treaties with them, the obligation of which she acknowledged.
\end{abstract}

Further, both the French and the English recognized the critical importance of alliances with the Indians [Aboriginal nations], or at least their neutrality, in determining the outcome of the war between them and the security of the North American colonies. ${ }^{190}$

Treaties of protection have been construed by the Supreme Court of the United States as "an [Aboriginal] nation claiming and receiving the protection of one more powerful, not that of individuals abandoning their national character, and submitting as subjects to the laws of a master." 191 Therefore, they remained "distinct political communities, having territorial boundaries, within which their authority is exclusive, and having a right to all the lands within those boundaries, which is not only acknowledged, but

Report of Commissioners for Treaty 8 (Winnipeg, Man., 22 September 1899), reprinted (Ottawa: Queen's Printer, 1966) at 6, cited in Horseman, supra note 1 at 929.

Treaty 7 Elders, supra note 83; Treaty 8 Elders in L. Hickey, R.L. Lightning \& G. Lee, findings in "T.A.R.R. Interview with Elders Program" in The Spirit of the Alberta Indian Treaties, supra note 83 at 103-12 (The main discussion of the treaty by most elders concerns hunting, fishing, and trapping and how rights to pursue their traditional livelihood were not given up and were even strongly guaranteed in the treaty to last forever: at 106).

Badger, supra note 1 at 90-91 (paras. 39-40). In Horseman, Wilson J. for the dissenting justices stated: "[I]t seems to me to be of particular significance that the Treaty 8 Commissioners, historians who have studied Treaty No. 8, and Treaty 8 Indians of several different generations unanimously affirm that the government of Canada's promise that hunting, fishing and trapping rights would be protected forever was the sine qua non for obtaining the Indians' agreement to enter into Treaty No. 8. Hunting, fishing and trapping lay at the centre of their way of life. Provided that the source of their livelihood was protected, the Indians were prepared to allow the government of Canada to 'have title' to the land in the Treaty 8 area" (supra note 1 at 911 ). Sioui, supra note 1 at 1054, citing Worcester v. State of Georgia, 31 U.S. (6 Pet.) 515 at 548-49 (1832) [hereinafter Worcester].

191 Ibid. Also "a weak state, in order to provide for its safety, may place itself under the protection of one more powerful, without stripping itself of the right of government, and ceasing to be a state" (at 560). Also see dissent in Cherokee Nation, supra note 81 at 52-55. 
guaranteed by the United States." 192 The Court reinforced these points in its decision in Worcester, when it interpreted the third article of the 1791 Treaty of Holston with the Cherokee Nation: ${ }^{193}$

The third article acknowledges the Cherokees to be under the protection of the United States of America, and no other power. This stipulation is found in Indian treaties, generally. It was introduced into their treaties with Great Britain.... The Indians perceived in this protection only what was beneficial to themselves - an engagement to punish aggressions on them. It involved, practically, no claim to their lands, no dominion over their persons. It merely bound the nation to the British crown, as a dependent ally, claiming the protection of a powerful friend and neighbour, and receiving the advantages of that protection, without involving a surrender of their national character. This is the true meaning of the stipulation, and is undoubtedly, the sense in which it was made. Neither the British government nor the Cherokees ever understood it otherwise.... Protection does not imply the destruction of the protected. ${ }^{194}$

This protective relationship in the treaties created a fiduciary relationship between the two parties. ${ }^{195}$

Beyond the concept of protection, of Aboriginal livelihood, the relationship between Aboriginal intent and Crown intent is a vexing problem. Yet the question remains: what are courts to do when the historical context and intent of a treaty is ambiguous? In Sioui, Lamer J. struggled with the absence of any express mention of the territorial scope in the treaty. ${ }^{196}$ In this case he stated:

[I]t has to be assumed that the parties to the treaty of September 5 intended to reconcile the Hurons' need to protect the exercise of their customs and the desire of the British conquerors to expand. Protecting the exercise of the customs in all parts of the, territory frequented when it is not incompatible with its occupancy is in my opinion the most reasonable way of reconciling the competing interests. This, in my view, is the definition of the common intent of the parties which best reflects the actual intent of the Hurons and of Murray on September 5, 1760. Defining the common intent of the parties on the question of territory in this way makes it possible to give full effect to the spirit of conciliation, while respecting the practical requirements of the British. This gave the English

Worcester, ibid. at 559.

193 In specific context, the Court was interpreting the Cherokee Nation treaty (1785) with the United States. The preamble stated the United States promised to "give peace to all the Cherokee, and receive them into the favour and protection of the United States of America on the following conditions," 28 November 1785, 7 U.S. Stat. 18; renewed 1791 (art. 1). Article 3 of the Treaty of Holston (1791) provided: "The said Indians do acknowledge themselves and all their tribes to be under the protection of the United States and no other sovereign" 7 U.S. Stat. 39 [emphasis added]. This was a common treaty article in the United States, but no limiting terms such as emphasized appear in Indian treaties with the imperial Crown. 
the necessary flexibility to be able to respond in due course to the increasing need to use Canada's resources, in the event that Canada remained under British suzerainty. ${ }^{197}$

This is an example of a failed attempt to understand common intent. It imposes intents that are inconsistent with the text of the treaty of $1760,{ }^{198}$ and it ignores that the British were the protectors and allies of the Huron Nation, not its conquerors. The treaty does not grant the Crown any land rights, nor does it talk about the British desire to expand, or about any practical requirements the British may have had. If no agreement was reached as to territorial limits, then the Crown did not acquire any territorial interest (and it became an issue of Huron law until extinguished by clear and plain acts). The defeat of the French had no effect on Aboriginal tenure, rights and use, as this was the intent expressed by the Crown and illustrated in art. 40 of The Act of Capitulation $^{199}$ and in the Royal Proclamation of $1763 .{ }^{200}$ The common intent expressed by Lamer $J$. and the court was a self-serving imaginary construct.

\section{B. Crown Obligations to Create an Enriched Way of life}

Equally as important as retaining the old ways in the treaty was the overarching intent of the Chiefs to obtain a useful partner in creating an enriched way of life. The Treaty Commissioner and the Chiefs were concerned with "a new life [which] was dawning upon them."201 Morris gave his assent to the new way of life upon which the Aboriginal peoples were insisting.

The Crown's obligations for the new way were vested in the treaties. The treaties provide for single lump sum payments for land; annual annuities by census; setting reserves aside for the use and benefit of treaty families; moving cost and proportionate grants for three years; compensation for taking of reserve lands for public works; never disposing of reserve lands without band consent; maintaining schools, teachers, building and education equipment for Indians on reserves; dealing with intruders; relief from calamities, pestilence, and famine; medical treatment; provision for powder and shot, twine, blankets, clothes for each Indian; seeds, agricultural assistance, farm stock, equipment, tools on reserves; funding; medals and flags; copies of treaties; horse and

Ibid. at 1071. Compare discussion of Aboriginal title in Van der Peet, supra note 39 at 194-201 (paras. 33-46), per Lamer C.J.C.; Adams, supra note 39 at 10-13 (paras. 25-30), per Lamer C.J.C.; Côté, supra note 39 at $41-47$ (paras. 35-49), per Lamer, C.J.C.

Sioui, supra note 1 at 1031 . The text of the treaty states: "THESE are to certify that the CHIEF of the HURON Tribe of Indians, having come to me in the name of His Nation, to submit to His BRITANNICK MAJESTY, and make Peace, has been received under my Protection, with his whole Tribe; and henceforth no English Officer or party is to molest, or interrupt them in returning to their Settlement at LORETTE; and they are received upon the same terms with the Canadians, being allowed the free Exercise of their Religion, their Customs, and Liberty of trading with the English: - recommending it to the Officers commanding the Posts, to treat them kindly." Cited in Sioui, supra note 1 at 1062.

200 Ibid. at 1063-65.

201 Morris, supra note 44 at 185. See generally S. Carter, Lost Harvests: Prairie Indian Reserve Farmers and Government Policy (Montreal \& Kingston: McGill-Queen's University Press, 1990) at $1-78$. 
harness (or a yoke or oxen) and wagon, carts or buggy; rifle and clothing for each Chief and Headman. ${ }^{202}$

As Beardy stated to the Treaty Commission at McKay Camp:

I feel grateful for this day, and I hope we will be blessed. I am glad that I see something that will be of use; I wish that we all as a people may be benefited by this. I want that all these things should be preserved in a manner than they might be useful to us all; it is in the power of men to help each other. ${ }^{203}$

\section{The Honour of THE Crown}

Canadian courts have made it clear that the honour of the Crown is involved in vested treaty rights. Thus, in construing the intent of the Crown, the courts have prohibited any attribution of sharp dealing or dishonourable conduct by the Crown, acting under the aegis of ministers of the Crown, toward Aboriginal nations. It makes no difference whether the sharp dealings are in the negotiations or drafting of the treaties, or in the implementation of them. The courts have firmly stated that they do not tolerate or condone such conduct by the Crown.

The Supreme Court of Canada has stated that the honour of the Crown is always at stake in its dealings with Aboriginal peoples. Interpretations of treaty or Aboriginal rights "must be approached in a manner that maintains the integrity of the Crown. It is always assumed that the Crown intends to fulfil its promises."204 Thus, reviewing courts cannot interpret Crown intent in any manner that dishonours the Crown. ${ }^{205}$ This notion assumes formal equality between the treaty parties. Where the Crown intentionally negotiated a treaty from a grossly unequal bargaining position, the courts will not allow an interpretation that suggests sharp dealing or trickery. ${ }^{206}$ Sharp dealing or unjust constructions cannot invalidate the terms of the treaties as the Aboriginal nations originally understood them. ${ }^{207}$

The sui generis categorization and the sacred and inviolable nature of the agreement provides the extraordinary constitutional context and interpretative principles for examining the mutual intent of the treaties. The imperial Crown accepted the protection of the Aboriginal nations and no parliament, elected government, or officials of the Crown can extinguish, partially or otherwise, what is sacred and inviolable and created

See Treaties, supra note 51.

Morris, supra note 44 at 226.

See Badger, supra note 1 at 92 (para. 41); Sparrow, supra note 3 at 1107-08, 1114; Taylor, supra note 11 at 367.

George, supra note 56; White and Bob, supra note 73.

Ibid.

Taylor, supra note 11 at 360. In Re Kane, [1940] 1 D.L.R. 390 at 395 (N.S. Co. Ct), per McArthur J. 
by the valid prerogative power of the Monarch. ${ }^{208}$ Of course, this is not the history of the federal government's conduct. ${ }^{209}$

\section{INTERPRETING TREATY TEXT}

You may be assured that my Government of Canada recognizes the importance of full compliance with the spirit and terms of your Treaties.

\section{Queen Elizabeth II in Calgary, 5 July $1973^{210}$}

After understanding the historical and legal context of a treaty and the intent of the parties, the problem of textual interpretation must be confronted. A treaty text has three components: language, relationship, and authority. The agents of the Crown drafted the legal texts using legal concepts familiar in their language. The Aboriginal nations also recorded the treaties in their symbolic literacies and oral traditions. Courts should not consider that Indians could not remember the treaty terms or that Aboriginal nations let them disappear into a vacuum. ${ }^{211}$

To interpret treaty rights, the treaty text has to be read in light of the dual contexts and intents that led to the treaty. The interpretation must be obedient to the spirit, intent, and languages of both parties. The text is supposed to be a linguistic means of expressing a consensual allocation of promises and jurisdictional authority between the treaty parties. These allocations were expressed through different languages, each with distinct linguistic structures and meanings, and mediated by interpreters. These facts require a textual analysis of sui generis Indian treaties that is a different process from the usual statutory interpretation. ${ }^{212}$ In the past, the courts have often ignored the interpretative principles embedded in the treaty text and have placed more reliance on English law and convention than on the actual terms of the treaties.

Some treaties delegate to the Crown judicial review of certain cases. The Mikmaw and Maliseet ratification treaty to the Wabanaki Compact, $1725,{ }^{213}$ originally provided

See generally B. Kingsbury, Indigenous Peoples in International Law (Ph.D. Thesis, Faculty of Law, Oxford University, 1990) [unpublished] at 194; $R$ v. McLeod (1884), 8 S.C.R. 1 (S.C.C.), per Ritchie J. at 26; $R$ v. Robertson (1882), 6 S.C.R. 52, per Ritchie J at 122, 125, 126. Royal Commission Volume 1, supra note 1 at 176-78, 247-71.

210 Quoted by The Hon. J. Chretien, Minister of Indian Affairs, in the federal Government's claims policy statement of 8 August 1973. Also, The Rt. Hon. Pierre Elliott Trudeau, Prime Minister of Canada, in his address of 28 April 1980 to the "First Nations Constitutional Conference," Ottawa, acknowledged this remark. Taylor, supra note 11 at 364-67.

In statutes, it is always clear who the maker of the statute is and in what linguistic structure and values it was constructed. There is no such clarity with Aboriginal treaties. In treaties, at a minimum, the courts have to give mutual weight to each party's interpretation of the document as well as to constitutional separations of power that existed when the document was negotiated and signed.

213 Submission and Agreement of Delegates of the Pensbscot, Norrigewock, St. Johnes, Cape Sables and other tribes in Nova Scotia and New England, signed at Boston, Public Archives of Canada, Manuscript Group 11, Public Archives of Nova Scotia, Colonial Office 217, vol. 4 at 349. 
that "in case of any misunderstanding, quarrel or injury between the English and the Indians no private revenge shall be taken, but application shall be made for redress according to His Majestie's laws."214 The Mikmaw Compact of 1752 clarified the explicit nature of legal redress:

[A]Il Disputes whatsoever that may happen to arise between the Indians now at Peace and others His Majesty's Subjects in this Province shall be tryed in His Majesty's Courts of Civil Judicature, where the Indians shall have the same benefits, Advantages \& Privileges as any others of His Majesty's Subjects. 215

Simon refers to this dispute-resolution process. ${ }^{216}$

In the Victorian treaties, by contrast, the Chiefs and Headmen agreed to "become responsible to Her Majesty for the faithful performance by their respective bands on such obligation as shall be assumed by them."217 They accepted the continuing responsibility to exercise the powers of maintaining peace and good order in the ceded territory and to perform certain governmental and legal duties. ${ }^{218}$

By the English text of the treaties, according to English legal traditions, the imperial Crown formally acknowledged that the authority of the Aboriginal Chiefs was independent of the imperial Crown or the Dominion of Canada. Aboriginal authority and government emanated directly from Aboriginal customs, and the Crown did not create this authority or order. The Crown recognized it and guaranteed to the Chiefs and Headmen continuing Aboriginal authority over all Aboriginal peoples in the ceded territory. Thus, the Chiefs and Headmen did not exercise authority in the name of the Crown or in association with the Crown or as servants of the Crown. They exercised their authority by virtue of powers that were vested and maintained in almost all the Victorian treaties. ${ }^{219}$

4 July 1726. Public Archives of Canada, Manuscript Group 11, Public Archives of Nova Scotia, Colonial Office 217 , vol. 4 at 350 ; vol. 38 at 108 .

(22 November 1752) reprinted in P.A. Cumming \& N.H. Mickenberg, eds., Native Rights in Canada, 2d ed. (Toronto: Indian-Eskimo Association of Canada in association with General Pub., 1972) 307 at 308.

Simon, supra note 1 at 401.

See Treaty 2, supra note 51 at 10-11.

Henderson, "Empowering Treaty Federalism," supra note 25 at 258-60. In British law, these powers in the treaties can be compared to the Magna Carta in 1215 (J. C. Holt, Magna Carta (Cambridge: Cambridge University Press, 1965) at 317ff), which has been described as the first attempt to express in exact legal terms some of the leading ideas of constitutional government (W.S. Holdsworth, $A$ History of English Law, 3d ed. (London: Methuen, 1823) at 216). The Magna Carta had the character of a treaty, under which the king would be granted allegiance in retum for recognizing reciprocal duties toward the subjects (V. Bogdanor, The Monarchy and the Constitution (Oxford: Oxford University Press, 1995) at 4). Like the Magna Carta, the constitutional significance of peace and good order clauses in the Victorian treaties lies in two fundamental principles: first, that the Chiefs, similar to the Sovereign, council of barons, and baron, govern according to law and are accountable for the way they govern; second, the rights of the families and Indians in the treaty take precedent over all other laws (ibid. at 3 ).

See "Text of Treaties" (1997) 2 Justice as Healing 7. 
Additionally, the text of the peace and good order clause asserts that the undersigned Chiefs solemnly promise and engage to strictly observe the treaty. Moreover, the Chiefs promised they would aid and assist the officers of Her Majesty in bringing to justice and punishment any Indian offending against the stipulation of the treaty, or infringing the laws in force in the country so ceded. The peace and good order clause creates concurrent jurisdictions over Indians offending the stipulation of the treaties and laws in the territories. ${ }^{220}$

The text of the treaties created in the Chiefs an authority equal to the authority of other officers of the Crown, including law officers. ${ }^{221}$ Most Canadian treaty precedents arise from treaty Indians being charged for hunting and fishing contrary to stipulations in the treaties ${ }^{22}$ or from treaty Indians infringing the law in that jurisdiction. These Indians are prosecuted and punished ${ }^{223}$ without any involvement of the Aboriginal Chiefs in the administration of justice or punishment. These facts illustrate that Canadian courts are reluctant to apply all the terms of a treaty, and often adopt a partial interpretation of the treaty texts.

The Crown's written affirmation of the inherent power of the treaty Chiefs imposes a substantial and strict limitation on the power of the Crown and on those who derive their power from the Crown. By recognizing and affirming in the treaties the authority of the Chiefs to maintain peace and good order, the imperial Crown placed future restrictions on its authority over Aboriginal nations. As a consequence of the written treaties, these Aboriginal powers are vested, positive obligations, liberties, and rights under British law, and these powers have now been reaffirmed in the Constitution of Canada. Since the courts must recognize that in every part of public affairs the expression of the royal will is conclusive, the treaties are conclusive of the distribution of power in the involved territories. ${ }^{224}$

See Henderson, "Empowering Treaty Federalism," supra note 25 at 258-60; and J.Y. Henderson, "Indian Justice and Punishment Clauses of Victorian Treaties in Constitutional Law of Canada" (1997) 2 Justice as Healing 1. Compare to the variant phrases of "peace, order and good govermment" in British colonial constitutions used to grant legislative powers, discussed in Sir W. I. Jennings, Constitutional Law of Commonwealth, 3d ed., vol. 1 (Oxford: Clarendon Press, 1957) at 48-55. In Canada, see s. 91 of Constitution Act, 1867, supra note 62 and Hogg, supra note 26 at $435-466$.

M. Brass, "Treaty Chiefs and Attomey Generals in Canada" (1997) 2 Justice as Healing 4.

The treaties created and vested the right to hunt and fish and provided for the regulation of this right. In Treaty Number 8 (1899), for example, it states: “And Her Majesty The Queen HEREBY AGREES with the said Indians that they shall have right to pursue their usual vocations of hunting, trapping and fishing throughout the tract surrendered as heretofore described, subject to such regulations as may from time to time be made by the Government of the country, acting under the authority of Her Majesty, and saving and excepting such tracts as may be required or taken up from time to time for settlement, mining, lumbering, trading or other purposes." See Badger, supra note 1; Horseman, supra note 1.

McNeil, supra note 56.

A.V. Dicey, Introduction to the Study of the Law of the Constitution, 8th ed. (London: Macmillan, $1915)$ at 490 . This created the maxim of the common law that the Sovereign can do no wrong and is therefore incapable of authorizing wrong to be done (see Feather v. R. (1865), 6 B. \& S. 257 at 295-29). If the prerogative power is clearly established, the courts must take the same judicial notice of it as they take of any other rule of law (Elderton's Case (1703), 2 Ld. Raym. 978 at 980 
Other terms in the treaties further defined the interrelation of the Aboriginal nations to the Crown, and the rights, authority, and obligations of both parties. In Badger, Cory J. stated:

In exchange for the land the Crown made a number of commitments, [for example, to provide the bands with reserves, education, annuities, farm equipment, ammunition, and relief in times of famine or pestilence]. ${ }^{225}$

These liberties and rights were vested in the treaties.

To understand the terms of a treaty in the context and intent of the parties, the Supreme Court has created special interpretative principles that differ from the ordinary plain meaning rules of interpretation. These interpretive principles include rejecting the plain meaning of text; understanding the general relationship between Aboriginal languages and English; fair, large, and liberal interpretation of the treaty text in favour of Indians; and interpretations in favour of Aboriginal worldviews and aspirations.

\section{A. Rejecting the Plain Meaning of Text}

The common rule for interpreting written documents is textualism, which is an attempt to adhere to the plain meaning of the written word. ${ }^{226}$ Thus, the typical first step in formal judicial reasoning is to examine the text and determine its legal categorization. ${ }^{227}$ An implicit assumption of the rule of plain meaning is that communications are translatable.

The Supreme Court of Canada has rejected adherence to the plain meaning of the words in the text of a treaty. The Court asserts that the text of the treaty does not always record the full extent of the oral agreement. ${ }^{228}$ Cory J. stated:

The treaties, as written documents, recorded an agreement that had already been reached orally and they did not always record the full extent of the oral agreement: see Alexander Morris, The Treaties

of Canada with the Indians of Manitoba and the North-West Territories [Toronto: Belfords, Clark]

per Holt C.J).

22s Badger, supra note 1 at 91 (paras. 39-40). In Sioui, supra note 1 at 1068, Lamer J. stated: "In my view, the treaty essentially has to be interpreted by determining the intention of the parties on the territorial question at the time it was concluded. It is not sufficient to note that the treaty is silent on this point. We must also undertake the task of interpreting the treaty on the territorial question with the same generous approach toward the Indians that applied in considering earlier questions. Now as then, we must do our utmost to act in the spirit of Simon."

The intellectual tradition of the textualist school of treaty interpretation is looked at in E. de Vattel \& J.B. Scott, Le Droit Des Gens ou Principles de La Loi Naturelle, 2d ed. (Washington: Camegie Institution, 1916) at 156-57 (paras. 263-461) ("it is not permissible to interpret what has no need of interpretation").

See $R$. v. Wesley, [1932] 2 W.W.R. 337 [hereinafter Wesley], where McGillivray J.A. followed uberrima fida interpretation of the right to hunt in Treaty 4 with the Alberta Game Act at 351, 353. However, in Sikyea (C.A.), supra note 74 at 335-36, Johnson J.A. held that the legislation overlooked the obligation of the treaties (at 69-70). 
(1880), at pp. 338-42; Sioui, supra, at p. 1068; [p. 155 C.N.L.R] Report of the Aboriginal Justice Inquiry of Manitoba [Public Inquiry into the Administration of Justice and Aboriginal People; Winnipeg] (1991); Jean Friesen, Grant Me Wherewith To Make My Living [Winnipeg: TARR Centre] (1985). The treaties were drafted in English by representatives of the Canadian govemment who, it should be assumed, were familiar with common law doctrines. Yet, the treaties were not translated in written form into the languages (here Cree and Dene) of the various Indian nations who were signatories. Even if they had been, it is unlikely that the Indians, who had a history of communicating only orally, would have understood them any differently. As a result, it is well settled that the words in the treaty must not be interpreted in their strict technical sense nor subjected to rigid modern rules of construction. Rather, they must be interpreted in the sense that they would naturally have been understood by the Indians at the time of the signing. This applies, as well, to those words in a treaty which impose a limitation on the right which has been granted. See Nowegijick, supra, at p. 36 [SD.C.R. p. 94 C.N.L.R.]; Sioui, supra, at pp. 1035-36 and 1044 [S.C.R. pp. 133-34-139-40 C.N.L.R.]; Sparrow, supra, at p. 1107 [S.C.R., pp. 179-80 C.N.L.R.]; and Mitchell, supra, where La Forest J. noted the significant difference that exists between the interpretation of treaties and statutes which pertain to Indians. ${ }^{229}$

Sound reasons exist for rejecting a textualist interpretation of sui generis Indian treaties: the contrasting English-language styles of the pre-treaty conferences and the treaty texts present major interpretative problems; the interpretative methods used at the treaty conferences are ambiguous; the existence of outside promises made at the pre-treaty conferences but not recorded in the treaty texts questions the reliability of the treaty texts; and no intelligible guidelines exist for clearly understanding the treaty clauses.

The English text of the treaties, at its best, is fraught with ambiguity. Many different agents of the imperial Crown conducted the treaties. ${ }^{230}$ From the transcripts of the treaty negotiations it is clear that the treaty commissioners used informal, conversational language during the treaty negotiations, yet the treaties were written up in formal legal style. During the treaty negotiations, the treaty commissioners continually reassured the Indians of the protection of their livelihood and way of life, ${ }^{231}$ but none of these promises are found in the words of the treaty text. During the treaty negotiations, the treaty commissioners, especially Morris, adopted a paternalistic tone and used kinship metaphors that conformed to Aboriginal ways of thinking to describe the Crown's intent

Ibid. See also Report of the Select Committee on Aborigines, 1837, Vol. 1, Part II (Imperial Blue Book, 1837 nr VII. 425, Facsimile Reprint, C. Struik, Cape Town, 1966) ("a ready pretext for complaint will be found in the ambiguity of the language in which their agreements must be drawn up, and in the superior sagacity which the European will exercise in framing, in interpreting, and in evading them" (at 80).

The treaties define the authority of the Crown representatives. For example, Governors and Legislative Council, the Military, the Hudson Bay Company (White and Bob, supra note 73) and treaty commissioners. These agents of the Crown owe no duties to third-party interests during negotiations. The provinces have not been official signatories to any treaty $(R$ v. Batisse (1978), 19 O.R. (2d) 145 (Ont. Dist. Ct.) [hereinafter Batisse]). 
behind the treaties; ${ }^{232}$ this tone and these comments were never committed to the written text of the treaties.

Often, the treaty commissioner reported that the Chiefs and Headmen did not understand the procedure or the substance of the agreements. ${ }^{233}$ Each treaty commission had interpreters to translate the proceedings into the appropriate Indian language. Yet, interpreters had no standardized levels of competence. Interpretation is not a purely linguistic exercise, and the act of translating Aboriginal concepts into the English language must be guided by some theoretical principles. Any act of interpretation at the treaty conferences carried with it an ethical and legal responsibility to accurately interpret the categories and words. ${ }^{234}$ Interpreters of Aboriginal languages must also understand the spiritual and ecological nature of Aboriginal thought. Plain meaning interpretation and translations are inherently problematic. ${ }^{235}$

It is unlikely that the Aboriginal Chiefs were aware that the oral statements made at the pre-treaty conferences differed from most of the written text of the treaties. ${ }^{236}$ When a court discovers that a government official drafted the written treaty prior to concluding the treaty meeting and ceremonies with the Aboriginal nation, the court is particularly wary. In such situations, courts have found the text of the treaty to be irrelevant. ${ }^{237}$ Given these difficulties, how can a court be certain that the English text is not a fraud or sharp practice? ${ }^{238}$ How can an interpreting judge tell whether the drafter of the treaty has captured the dual understandings inherent in a treaty process? How can the court be assured that the wording of the treaty is not ambiguous?

Textual analysis of the treaties is complicated by a lack of skilled interpreters at the time of the treaty negotiations, and by the failure of the imperial Crown to translate the treaties into the languages of both parties. No special phonetic symbols appear in the minutes of treaty conferences or in treaty texts to capture the Aboriginal contribution to the discussion. There are no running guides - not translations into literate English but what professional translators would call "cribs" or "trots" - to the original

232 E.g., Treaty Commissioner Morris, supra note 44 at 95-96. Also see McKenna Report to Superintendent of Indian Affairs, reprinted in Treaty 10 (Ottawa: Queen's Printer).

233 Morris, $i b i d$ at 86 and 160 noted that some Indian groups claim that only preliminary negotiations had been completed the previous year; they rejected the idea that a treaty had been entered into. See Stanley's written version of Big Bear: G.F.G. Stanley, The Birth of Western Canada: A History of the Riel Rebellions (Toronto: University of Toronto Press, 1963) at 275.

$234 \quad$ Havel, infra note 245 at 19.

23s The common problems of textual interpretation involve: paraphrasis and metaphrasis; parataxis and syntactis; epistemological, aesthetic, and theoretical considerations. Additionally, the interpretation of treaty text involves the issues of linguistic and melodic coherence, accessibility, competence, authenticity, and the recording by others of the interpretation. Finally, there are the moral and political problems of resisting unifying Eurocentric theories and interpretative monopolies, and of confining the privilege of explaining Aboriginal worldview and languages to the Eurocentric academic discourse.

237 Bartleman, supra note 164 at 86; White and Bob, supra note 73 at 622 per Sheppard J.A. and 651 per Norris J.A. (Chiefs signed blank sheet). Royal Proclamation of 1763, supra note 185, cited the common practice of fraud in the colonies. 
exchange. With no phonetic or running guides to refer to, an interpreting justice has no insight into how Aboriginal Chiefs and Headmen expressed themselves or what concepts were agreed to. Without this essential documentation, it is impossible to determine the accuracy of the interpretation at the time of the treaty-making process. Even the transcripts of the negotiations, taken down by interpreters in shorthand at the negotiations, do not reveal an Aboriginal vantage point or an understanding of their comments. Because of the Crown's negligence, interpreting justices have very limited material with which to analyze Aboriginal intent or establish the accuracy of the translations of the written texts.

Textual analysis is also hindered by the presence of "outside" or "open" promises in the treaty negotiation process. Soon after the first treaties were written, the Chiefs and Headmen asserted that promises had been made to them in negotiations that had not been included in the written treaties. These claims show the difficulties of interpretation, fraud or carelessness on the part of the treaty commissioners, and the lack of Aboriginal understanding of the process. The federal government denied the validity of these claims, but settled them on the basis of "good feeling" or "benevolence." The 1875 Order-in-Council illustrates the government's position:

While the Government cannot admit to their claims [of Chief and Headmen of Treaty 1 and 2] to anything which is not set forth in the Treaties and in the memo attached thereto, which Treaty is binding alike upon the Govemment and upon the Indians, yet, as there seems to have been some misunderstanding between the Indian Commission and the Indians in the matter of Treaties 1 and 2, the Government out of good feeling to the Indians and as a matter of benevolence, is willing to raise the annual payment to each Indian under Treaty 1 and $2 \ldots$ on the express understanding, however, that each Chief and other Indians who shall receive such increased annuity or annual payment, against the Government in connection with the so called "Outside Promises", other than those contained in the memo attached to the Treaty. ${ }^{239}$

Many negotiations began with Chiefs complaining about unfulfilled promises. ${ }^{240}$

No intelligible guidelines exist for determining the plain meaning of a sui generis treaty text or for identifying an existing clarity of a text in a treaty. No intelligible guidelines exist for determining Aboriginal interpretations of treaties manifested through linguistic structures that are foreign to English. No intelligible principles guide the interpretation of what makes a certain text unclear or what level of ambiguity an interpreting judge must tolerate. In the absence of such principles, an interpreting judge must determine the proper threshold of ambiguity of text, intent, and context of a sui generis treaty. supra note 33. 


\section{B. Syntax PaRadoxes}

In the sui generis treaties, two different syntax structures seek to reach constitutional agreement. An interpreting judge must have a general understanding of the relationship between these structures ${ }^{241}$ and an awareness of linguistic and psychological inquiries surrounding dual linguistic agreements. These inquiries have been variously called generative grammatical structures, deep structure linguistics, mentalism, and cognitivism. ${ }^{242}$ These inquiries seek to unveil the abstract underlying structure of a particular language and the way sounds are put together to create meaning.

For example, in reading a treaty conference report or text, an interpreting judge needs to be constantly aware of his or her cultural and linguistic subjectivity, what anthropologists have called the "categorical abstraction" of English. ${ }^{243}$ Since different languages divide reality in different ways, categorizing meanings differently and establishing different patterns of thought, ${ }^{244}$ an interpreting judge must be aware of the linguistic relativism between English and Aboriginal categories. Since English may be inadequate to express Aboriginal values or concepts, an interpreting judge must know where the two languages differ and where they merge. ${ }^{245}$ No matter how interpreting judges attempt to finesse the problems of categorical abstraction in treaty texts, the question of interpretation and translation remains paramount. This issue subsumes all other topics in the interpretation of treaty texts. To understand an Aboriginal context and intent, a treaty text must be read with respect for both languages and their structures and categories.

One reason there is no unified syntax in the sui generis treaties is that the written English text attempts to express concepts from verb-based Aboriginal languages in a noun-based form. ${ }^{246}$ Often, these differences in syntax create a great and unbridgeable

Language, Thought and Reality, supra note 91; and L.S. Vygotsky, Thought and Language (Cambridge, Mass.: MIT Press, 1962). See generally about the Aboriginal language context, $R$. Ross, Returning to the Teacnings: Exploring Aboriginal Justice (Toronto: Penguin Books, 1997) especially at 76-130. (Cambridge, Mass.: MIT Press, 1965). The goal of generative linguistics was to identify a grammatical structure that defines a finite set of rules that would generate all (and only) the grammatically acceptable sentences of a language. This theory replaced structural linguistics, which categorized utterances of a language or verbal behaviour. Earth, D. Tedlock \& B. Tedlock, eds. (New York: Liverright, 1975) at 144. Language, Thought and Reality, supra note 91 at 213-14. Whorf used Aboriginal languages as his example.

245 Vaclav Havel, the playwright and leader of the Czech Republic, stated: "Words that electrify society with their freedom and truthfulness are matched by words that mesmerize, deceive, enflame, madden, beguile, words that are harmful - lethal, even. The word as arrow." "Words on Words," New York Rev. of Books (18 January 1990) at 11.

Meet Cree, supra note 172 at 45-48, see especially 47 . See generally The Implicate Order, supra note 88 at 295-301; D.R. Kelley, "Gaius Noster: Substructures of Western Social Thought" in History, Law and the Human Sciences (London: Variorum Reprints, 1984) 619. 
linguistic void between the dual understanding of the treaty by its signatories. ${ }^{247}$ These issues are more troubling if several Indian tribes with different languages were involved in the treaty negotiations or accessions.

From an Aboriginal understanding, the English text is both creative and inhibiting. The English texts reflect a word world of an artificial legal society, not an objective reality. ${ }^{248}$ This legal word world is a fragmented one, composed of quantifying intangibles and imaginary nouns, and perceiving time in terms of past, present, and future. These word worlds were unknown to the Aboriginal treaty signatories. Thus, when the treaties talk about "Her Most Gracious Majesty," Aboriginal thought conceptualizes an existing being rather than an intangible legal entity. In Aboriginal thought, a human being can express his or her "will," whereas a state or nation cannot since states and nations are imaginary nouns or abstract entities. Aboriginal thought viewed the treaty commissioners as speakers for Her Majesty, just as they had delegates to speak for them. The treaty text turns both the treaty commissioners and the Chiefs and Headmen into abstract entities. ${ }^{249}$ In the English legal word world, the commissioners were agents of the Crown surrounded by technical rules derived from international and domestic law. By English rules, their legal authority is metaphoric, it can be either textual or contextual, e.g., implied or ostensible. ${ }^{250}$ These understandings were unknown to Aboriginal thought. ${ }^{251}$

An example of this syntax quandary in Canadian courts is found in the 1889 case of Ontario (Attorney General) v. Francis, ${ }^{252}$ when the Chancery Division of the Ontario

E.g., Jones v. Meehan, 175 U.S. 1 at 11 (1899) [hereinafter Jones]; Whitefoot v. United States, 293 F. 2d 658, 667 n.15 (Ct. Cl. 1961), cert. denied 368 U.S. 8181 (1962) [hereinafter Whitefoot]. This is called the subjective value of knowledge in modem thought (Knowledge and Politics, supra note 79 at 76 ).

249 In all the Georgian and Victorian treaties, for example, (see Keiter, supra note 51 at 43 fourth paragraph of Treaty 4) the text recognizes that there are properly selected Headmen and Chiefs who were specifically appointed by the Aboriginal people through the internal structures of each First Nation to negotiate and maintain the duty to see that the treaty was fully performed. The Victorian treaties, for example, read: "AND WHEREAS the Indians of the said tract, duly convened in council at the respective points named hereunder, and being requested by Her Majesty's Commissioners to name certain Chiefs and Headmen who should be authorized on their behalf to conduct such negotiations and sign any treaty to be founded thereon, and to become responsible to Her Majesty for the faithful performance by their respective bands of such obligations as shall be assumed by them, the said Indian have theretofore acknowledged for that purpose the several Chiefs and Headmen who have subscribed hereto." Then their names are listed. This is recognition of the existence of a separate Aboriginal constitutional system based on the will of the people instead of rule from above. The Aboriginal system did not derive its authority from the British legal system, but was expressly confirmed in the text of the treaty.

See G.K.L. Fridman, Law of Agency, 6th ed. (London: Butterworths, 1990) at 59-69, 107-18; and the dual understanding test of Sioui, supra note 1 at 1040: the very important, authoritative functions of representing the Crown and reasonable beliefs of the Indians, i.e., implied or ostensible authority.

Wewayakum Indian Band v. Wewayakai Indian Band, (1991) 42 F.T.R. 40. Addy J. admitted that no rule of Canadian law governed the representation of an aboriginal peoples, such rules must be found among their traditions (at 45). This is similar to the Vienna Convention, supra note 21, art. 46. 
High Court had to interpret the scope of Aboriginal lands that the 1850 treaty had reserved to the Ojibwa Indians as Wababutaseje (lands near Whitefish Lake). Ferguson H.J.C. had to confront the meaning of the categorical abstraction of the term "seven miles inland." He stated:

The words in the schedule of the treaty are certainly very meagre for this purpose. I may first dispose of the concluding words "seven miles inland" by saying that after hearing the evidence that was given in regard to the Indians' understanding, or rather want of understanding, of the meaning of the word "mile"; ... and the evidence as to the word in their language used by them indiscriminately to signify the measure of distance or any other measure such, for instance, as a bushel; counsel very properly, I think, abandoned any contention resting upon the use of these words.... Where I take into account the facts that the only word, as I have before said, that these Indians have to signify the measure of distance, is equally applicable to other measures; that they did not and do not yet know what distance is meant by a mile, reckoning, as they do, their distances by the length of time occupied in travelling over them, and being unable to express in so doing fractional parts of a day; together with their manifest inability to make a sketch or diagram to represent a tract of land; I think it impossible to say that any argument against the present claim of these Indians resting upon such a foundation can prevail, even though such charts or diagrams should apparently differ widely from one really representing what I think has been shown to be the reserve, and any and every argument against the contention of the Indians as to the area of land really in the reserve, or its location, which is based upon anything they or any of them may have said or represented in regard to distance or expanse, must give way to the conclusion having its foundation upon actual facts ascertained by evidence respecting the immovable objects upon the ground. They did not and do not know what is meant by a mile, or a league, or the difference between the two measures, nor indeed any measure that to us would be a measure at all. ${ }^{253}$

Instead of the English categories of measure, the High Court relied on the testimony of the Chief of the Band, who had been with his father at the treaty conference, and his Ojibwa description of the lands reserved.

[I] find that it is shown by the evidence, that the band at the time of the treaty were in occupation (in the way, and the only way, they could in their manner of living occupy territory: that is, by their plantations, their sugar bushes, their burial grounds, hunting, fishing, etc.) of the parcel of land embraced by the nine marks - immovable marks - mentioned by the witness Mongowin the present chief; that is, if lines be reasonably drawn from one mark to the other all the way around the tract of land. ${ }^{2 s}$

\section{Contemporary evidence confirms this judicial insight.}

The Aboriginal worldview in oral translations, words, rituals, and ceremonies is distinct from written English conventions. In the oral traditions of Aboriginal people,

one stands in a different relation to language. Words are rare and therefore clear. They are zealously preserved in the ear and in the mind. Words are spoken with great care, and they are heard. They 
matter greatly, and they must not be taken for granted, they must be taken seriously, and they must be remembered. 2 ss

For example, in the oral tradition, the last items agreed to are the most important and create the context for interpreting all other comments. Given our current knowledge about the very different structure of languages and assumptions about Aboriginal oratory and the oral tradition, an interpreting judge cannot help but question if any satisfactory interpretative strategy was used in the formation of the treaty text. Also, it is questionable whether any dual standard of linguistic fidelity to the original sources existed in either the treaty text or conferences. ${ }^{256}$

The absence of guidelines for understanding the sui generis treaties makes them different from most European treaties. ${ }^{257}$ The Vienna Convention of treaty interpretation, for example, does not address situations where the parties lacked a common language of negotiation. In the case of the sui generis treaties, only one party recorded the agreements, and this party couched the agreements in technical vocabulary that was almost certainly unfamiliar to the other party. ${ }^{258}$ There are, however, other rules that can help resolve some of these linguistic dilemmas.

\section{FAIR, LARGE, AND Liberal INTERPRETATION OF TREATY TEXT IN FAVOUR OF INDIANS}

Before 1982, Canadian courts had already settled that any ambiguity in a treaty text should be liberally construed or interpreted favourably to the Indians. ${ }^{259}$ This concept is derived from the general principle of contract law that reviewing justices must interpret a document against its framers (contra proferentem) ${ }^{260}$ In textual analysis, this principle asserts that an interpreting judge shall liberally construe the terms of treaties to carry out the apparent intentions of the Indians, the non-framers of the treaties, to secure a semblance of equality and reciprocity between the treaty parties. Under this interpretive principle, the wording of the treaties must be understood from

N. Scoot Monaday, a Kiowa-Navajo writer, "The Native Voice in American Literature" in E. Eliott, ed., Columbia Literary History of the United States (New York: Columbia University Press, 1988) 1 at 6.

On the problems of translation, see generally D. Hymes, "In Vain I Tried to Tell You" in Essays in Native American Ethnopoetics (Philadelphia: University of Pennsylvania Press, 1981), especially at 39-40. Also see B. Swann, ed., On the Translation of Native American Literatures (Washington: Smithsonian Institution Press, 1992), especially D. Bahr, "Translating Papago Legalese" at 257-75; B. Swann \& A. Kruput, eds., Recovering the Word: Essays on Native American Literature (Berkeley: University of California Press, 1987), especially R. Kaiser, "Chief Seattle's Speech(es): American Origins and European Reception" at 497-536.

For a discussion of international treaty protocol, see J. Starke, An Introduction to International Law, 6th ed. (London, Butterworths, 1967) at 346-63.

Wesley, supra note 227 at 340; Batisse, supra note 230.

$260 \quad R$ v. Cooper (1969), 1 D.L.R. (3d) 113 at 115 (B.C.S.C.); Taylor, supra note 11 at 367; see also Abrahams v. Canada (A.G.), [1983] 1 S.C.R. 2 at 10 (social benefits schemes should be construed in favour of the recipients). 
the Indians' perspective, rather than from the perspective of the laws of England and Canada.

This interpretive principle protects Indian treaties from the technical legal English and local reading by the Crown. It asserts the paramountcy of Indian expectations and Aboriginal law. Where a treaty text admits of two constructions, one favourable to Aboriginal or Indian rights and another restrictive of them, the courts have mandated that the favourable judicial interpretation is preferred. Thus, when in doubt, an interpreting judge should construe in favour of granting treaty rights. This interpretative principle creates a set of interpretative values that are independent of evidence of intent. This same principle applies to Indian treaties in the United States, where treaties must also be liberally construed in favour of Indians. ${ }^{261}$

Doubtful expression is interpreted in favour of Indians as well. In Choate v. Trapp, ${ }^{262}$ where doubt existed about the nature of a tax exemption conferred on land allotted to the tribal citizens of the Choctaw and Chickasaw Nation by a federal act, United States Supreme Court justices conclusively presumed that Congress intended a valuable property right rather than a gratuity. The interpretive principle compelled the presumption that with respect to Indians' rights "doubtful expression" in subsequent statutes must be "resolved in favour of" the Indians. ${ }^{263}$ Because of this interpretive principle, it is sometimes necessary to recreate the historical context that existed at the time the treaties were negotiated.

Similarly, in resolving a conflict between an Indian treaty and the international Migratory Bird Convention, ${ }^{264}$ and implementing a federal act that was silent as to Indian hunting rights, a federal court held that congressional intent on the subject was ambiguous. In the face of ambiguity, the U.S. court resolved its doubts in favour of the Indian treaty rights:

[W] hen in considering treaties with Indians, and Acts of Congress relating to their rights, we should not forget the wellknown liberal application of the principle, that grants to them should be regarded "stictissimi juris" and all uncertainties resolved in their favor. ${ }^{20 s}$

Since 1982, the Supreme Court of Canada has applied this interpretive principle to all treaty text requiring a "fair, large and liberal" interpretation of any particular provision of a treaty. ${ }^{266}$ The Supreme Court has also held that an interpreting judge must read the text in the sense that the particular Aboriginal grantors at the time would

E.g., Choctaw Nation v. United States, 318 U.S. 423, $431-32$ (1943) [hereinafter Choctaw].

224 U.S. 665 (1912).

lbid. at 675-76.

(1916) Can. T.S. No. 628.

United States v. Cutler, 37 F. Supp. 724 at 725 (E.D. Idaho 1941).

Simon, supra note 1 at 402. 
naturally have understood. ${ }^{267}$ Once again, this leads the courts back to recreating the historical context of the treaty negotiations from an Aboriginal perspective.

This interpretive principle reflects the judicial desire to give special credence to the meaning ascribed to the treaty by one treaty partner, in this case the Aboriginal grantors. By placing a greater judicial value on the Aboriginal understanding at the time of the treaties, the courts are attempting to compensate for the lack of linguistic equality in the formation of the treaties. The courts are recognizing that Aboriginal treaty negotiators did not speak or read English and were not familiar with English or public international legal concepts. Different worldviews and linguistic structures affected the context of the treaties. ${ }^{268} \mathrm{~A}$ recognition of the unequal linguistic position of the Aboriginal Chiefs, the honour of the Crown, and the legally binding fiduciary obligations of the Crown has led to this interpretative principle, which is designed to rectify the inequality.

The Supreme Court of Canada has stated that neither the Crown's interpretation ${ }^{269}$ nor the technical meaning of the English words ${ }^{270}$ are allowed to defeat the Aboriginal understanding. The Court has also ruled that subsequent developments cannot be used to defeat the Aboriginal understanding at the time of the treaty negotiations. This is a judicial corollary of the Chiefs and Headmen solemnly promising and engaging to strictly observe the terms of the treaty.

Moreover, the Supreme Court has held that a reviewing justice cannot interpret any treaty terms or text to make the treaty promises ineffective in their modern application. The Court's reasoning is that the obligations are continuous. ${ }^{271}$ For example, in Simon, the Supreme Court held that the right to hunt and fish "as before" could not be interpreted as meaning only pre-treaty techniques or methods were available to hunters. ${ }^{272}$ The unanimous court held that techniques and methods change with times. This ruling is the result of a principled search to uphold the purposes and promises of the Crown to the Mikmaq.

Nowegijick, supra note 13 at 36; Halsbury's, supra note 62, vol. 18 at para. 1793, cited in Horse, supra note 106, and Howard, supra note 30; Worcester, supra note 190 at 515, 551-54, 582; Jones, supra note 247 at 10-11, followed in Simon, supra note 1, and Sioui, supra note 1 at 1055, established the importance of language construction and linguistic inequities in the Indian treaties. See also Whitefoot, supra note 247; Duwamish Indians v. United States, $79 \mathrm{Ct}$ Cl. 530 (1934). The lack of skilled interpreters and the failure to translate the treaty into the languages of both parties are factors unique to Aboriginal treaties. Sioui, supra note 1 at 1036, citing Jones, supra note 247.

R. v. Blackfoot Band of Indians, [1987] 2 C.N.L.R. 63 (F.C.T.D.) (Treaty 7) (terms of treaties should be interpreted against the drafters of such treaties and not to the prejudice of Indians).

Can. (A.G.) v. Ontario (A.G.); Quebec (A.G.) v. Ontario (A.G.), [1897] A.C. 199 (P.C.).

Sioui, supra note 1; Simon, supra note 1; Nowegijick, supra note 13. See also U.S. cases: Choctaw Nation v. Oklahoma, 397 U.S. 620, 631 (1970); Choctaw, supra note 261; Worcester, supra note 190 at 582. Similar principles have been affirmed by the First Ministers of Canada in s. 35.6(1) of the Charlottetown Accord (Draft Legal Text, 9 October 1992) that remains a constitutional convention of Canada.

Simon, supra, note 1 at 403 (Treaty of 1752). Compare to the aboriginal rights definition in Van der Peet, supra note 39. 
Interestingly, the Supreme Court has not applied this rule to modern land claim agreements, such as the James Bay Agreement. ${ }^{273}$ Additionally, in the Nunavut Land Claim Agreement the parties agreed that "[t]here shall not be any presumption that doubtful expressions in the Agreement be resolved in favour of Government or Inuit."274

\section{IN FAVOUR OF ABORIGINAL WORLDVIEW AND ASPIRATIONS}

Since any treaty text must be construed in favour of the Indians, an interpreting judge must determine how to interpret a clause in favour of the Indians. This is not resolved by the justice speculating about Indian worldview, languages, and motivation; these must all be part of the evidence provided.

In the colonial era, Aboriginal worldview, languages, and motivations were not considered a legitimate part of Canadian thought or law. Aboriginal thought was considered to be savage or primitive. Most modern commentary and research continues to be focused on federal or English law. The treaty terms, however, are not the product of legislation, but derive from the promises of the treaty parties. Therefore, to understand the spirit and terms of a treaty, the interpreting court must interpret the treaty according to the sense or spirit in which the Aboriginal people would naturally have understood it. ${ }^{275}$ This leads to the interpreting principle of fair, large, and liberal interpretation of the treaty text in favour of the Indians. ${ }^{276}$ This is partially because the Aboriginal people were the grantors in the treaties, and partially because the Aboriginal negotiators were not strictly accountable for the nuances of the foreign English treaty text. ${ }^{277}$

As mentioned before, Aboriginal worldview and thought is distinct from British worldview and thought. Similarly, Aboriginal law is distinct from the collective or personal rights context of the constitutional interpretation of Canadian thought. ${ }^{278}$ Professor Linda Medcalf has illustrated how American lawyers and judges have unwittingly contributed to the destruction of Indian culture as they acted as well-intentioned liberators. ${ }^{279}$ She illustrates how they translated their beliefs about Indian aspirations into Eurocentric and material terms. They sought to secure and maintain for the Indians a significant measure of government and administration over their reserves and resources, but they did not provide the Indians with a meaningful

Eastmain, supra note 107; and Howard, supra note 30.

Agreement between the Inuit of the Nunavut Settlement Area and Her Majesty the Queen in Right of Canada (Ottawa: Underjoint Authority of the Tungavik Federation of Nunavut, 1993). section 2.9.3. See also Gwich' in Agreement, section 3.1.20.

Supra note 252; see also Badger, supra note 1 at 91, 95 (paras. 41, 52).

Simon, supra note 1; Nowegijick, supra note 13 at 198; relying on Jones, supra note 247, which followed Worcester, supra note 190.

Ibid:; P.P. Frickey, "Marshalling Past and Present: Colonialism, Constitutionalism, and Interpretation in Federal Indian Law" (1993) 107 Harv. L. Rev. 381-440, especially at 397-98.

See Wilson J. in Horseman, supra note 1 at 912.

L. Medcalf, Law and Identity: Lawyers, Native American, and Legal Practice (Beverly Hills: Sage Publications, 1978). 
choice between assimilation into American society and maintaining their culture. According to Medcalf, legal strategies developed for enhancing power and wealth on the reserves ran at cross-purposes to the Indians' efforts to keep their cultural options open. The consequence was that they copied American political forms and imposed these alien forms on Aboriginal society. In this way the forces of Eurocentric thought operated within American legal consciousness.

The same forces are at work in Canadian legal consciousness. Interpreting judges who have to determine how to construe a treaty clause in favour of the Indians must be wary of these forces. What is required is to use law as a means of entering into Aboriginal consciousness and order.

\section{CONClusion}

The interpretative principles stipulated by the Supreme Court of Canada are an attempt to affirm and enhance Aboriginal worldviews and cognitive diversity within the Constitution of Canada. This attempt is one of the most difficult and pressing questions in judicial interpretation of modern constitutional order. ${ }^{280}$ These principles require a redefinition of treaty assumptions and terms. The interpretive principles are designed to enhance and preserve Aboriginal context, intent, and interpretation in constitutional interpretation. They are designed to remove colonialist and racist biases from constitutional interpretation. They force interpreting judges to challenge the assumptions of colonization, to interpret treaties flexibly to promote the new constitutional order of Canada, and to refuse to relieve Parliament of its treaty obligations and responsibilities toward the Indians. ${ }^{281}$

Aboriginal peoples and their lawyers must help the courts peel away the layers of misunderstanding in constitutional law and its subordinate legislation and regulations. Aboriginal thinkers must reassess Eurocentric prejudices, correct biased perspectives and, in their place, reveal Aboriginal treaty perspectives and post-colonial thoughts. In asserting Aboriginal and treaty rights, Aboriginal lawyers must point out the bias and prejudice that originates in the English language and the Eurocentric worldview. This requires critical and extensive examination of all existing sources and interpretations. After all, Canadian federalism is a governmental system that is designed to protect the cultural, linguistic, and regional diversity of the nation.

For an interpreting judge who must reconcile federal power with constitutional rights or duties, the Supreme Court has stated that the best way to achieve this reconciliation is to demand the consistency or supremacy test with the context, intent, and terms of a treaty. ${ }^{282}$ The consistency or supremacy test is the standard test for treaties ${ }^{283}$ and

See, generally, J. Tully, Strange multiplicity: Constitutionalism in an age of diversity (Cambridge: Cambridge University Press, 1995).

See generally Frickey, supra note 277.

Section 52(1) of the Constitution Act, 1982, supra note 17.

Manitoba Reference, supra note 17; New Brunswick (A.G.) v. C.P.B. and Canada (A.G.) (1925),

2 D.L.R. 732 (P.C.). 
is a stricter test than the justification for any government regulation that infringes upon or denies Aboriginal rights. ${ }^{284}$ Such strict scrutiny is consistent with the text of the treaties and in keeping with the treaty interpretive principles enunciated in Nowegijick. It also adheres to the concept of holding the Crown to a high standard of honourable dealing with respect to the Aboriginal peoples of Canada. ${ }^{285}$

Last, but foremost, special attention must be given by the judiciary to make the Elders who are fluent in their Aboriginal languages and know the teachings a part of the judicial decision-making process for Indians who have offended against the treaties. Justice requires that Elders should be special masters or judges in trials that confront treaty interpretation. Alternatively, justice also requires that Treaty courts be established by Elders and Indian lawyers to interpret the treaties for offending Indians under the justice and punishment clauses. No better way exists to understand the legal order embedded in the Aboriginal languages. 